\title{
Overexpression of chitotriosidase and YKL-40 in peripheral blood and sputum of healthy smokers and patients with chronic obstructive pulmonary disease
}

This article was published in the following Dove Press journal:

International Journal of Chronic Obstructive Pulmonary Disease

\section{Sebastian Majewski \\ Damian Tworek ${ }^{2}$ \\ Karolina Szewczyk' Justyna Kiszałkiewicz ${ }^{3}$ \\ Zofia Kurmanowska' \\ Ewa Brzeziańska-Lasota ${ }^{3}$ \\ Hanna Jerczyńska ${ }^{4}$ \\ Adam Antczak ${ }^{2}$ \\ Wojciech Jerzy Piotrowski ${ }^{1}$ \\ Paweł Górski' \\ 'Department of Pneumology and Allergy, Medical University of Lodz, Lodz, Poland; ${ }^{2}$ Department of General and Oncological Pulmonology, Medical University of Lodz, Lodz, Poland; ${ }^{3}$ Department of Molecular Bases of Medicine, Medical University of Lodz, Lodz, Poland; ${ }^{4}$ Central Scientific Laboratory (CoreLab), Medical University of Lodz, Lodz, Poland}

Correspondence: Sebastian Majewski Department of Pneumology and Allergy, Medical University of Lodz, 22

Kopcinskiego Street, 90-I53 Lodz, Poland Fax +48 426782129

Email sebastian.majewski@umed.lodz.pl
Background: Despite the absence of endogenous chitin in humans, chitinases are present in the serum of healthy subjects and their levels are increased in a variety of chronic inflammatory conditions. It has been shown that chitotriosidase and structurally related chitinaselike protein-YKL-40 contribute to the pathogenesis of COPD. However, details regarding the relation of their systemic and local airways levels remain unknown.

Objectives: To examine peripheral blood and sputum chitotriosidase and YKL-40 expression in smokers and patients with COPD.

Methods: Forty patients with COPD, 20 healthy smokers and 10 healthy never-smokers were studied. Serum and induced sputum chitotriosidase protein and activity levels, YKL-40 concentrations, and their gene expression in sputum cells and peripheral blood mononuclear cells (PBMC) were evaluated.

Results: Both chitotriosidase protein levels and activity were higher in sputum obtained from COPD subjects compared to healthy never-smokers ( $P<0.05$ and $P<0.01$, respectively). A similar pattern was observed for PBMC chitotriosidase mRNA expression $(P<0.001)$. YKL-40 serum concentrations were elevated in healthy smokers and COPD subjects compared to healthy never-smokers $(P<0.001$ and $P<0.01$, respectively). In sputum, YKL-40 levels were increased in COPD compared to healthy never-smokers $(P<0.01)$. PBMC YKL40 mRNA expression was increased in COPD and healthy smokers compared to healthy never-smokers $(P<0.0001)$. No associations were found between chitotriosidase or YKL-40 peripheral blood levels and sputum levels.

Conclusions: Our results demonstrate that chitotriosidase and YKL-40 are overexpressed in peripheral blood and airways in both healthy smokers and COPD subjects which may indicate smoking-related activation of macrophages, neutrophils, and epithelial cells.

Keywords: chitotriosidase, CHIT1, YKL-40, chitinase, chitin-like protein, COPD

\section{Introduction}

Chitin is a linear, carbohydrate polymer which is a structural component of the cell walls of bacteria, fungi, the exoskeletons of crustaceans, the sheaths of parasitic nematodes, and the lining of the digestive tracts of many insects. This polysaccharide protects chitin-containing organisms against environmental threats. ${ }^{1}$ Those species have numerous genes encoding hydrolases with chitinolytic activity-chitinases, permitting the chitin metabolism required for their growth and development. The best-known chitinases belong to members of 18 glycosyl hydrolase gene family, widely expressed 
in a range of organisms from prokaryotes to eukaryotes. True chitinases including chitotriosidase (chitinase 1/CHIT1) and acidic mammalian chitinase (AMCase) are active enzymes able to bind and degrade chitin. ${ }^{2-4}$ Many organisms, in addition to chitinases, produce various structurally related proteins without chitinolytic activity, such as chitinase 3-like 1 (CHI3L1/YKL-40), which bind with high affinity the chitin polysaccharide. Those proteins without enzymatic activity are known as chitinase-like proteins or chi-lectins. ${ }^{1,5}$ Despite the absence of endogenous chitin in humans, chitinases and chitinase-like proteins are present in healthy subjects and show dysregulated expression in a variety of both acute $^{6-10}$ and chronic disease conditions, ${ }^{11-23}$ including lung diseases with inflammation and tissue remodeling. ${ }^{24-39} \mathrm{~A}$ growing body of evidence suggests regulatory functions of both chitotriosidase and YKL-40 on innate immune pathways which affect not only host defense but also tissue injury and repair responses.

COPD is characterized by chronic airway inflammation and alveolar destruction leading to emphysema. A widely accepted hallmark of COPD is an abnormal response to inhaled particles which have the potential to initiate inflammation and lung injury. ${ }^{40,41}$ Recently, chitinases appeared as an interesting biomarker in COPD. Numerous studies showed increased levels and/or activity of chitotriosidase and/or YKL-40 in bronchoalveolar lavage (BAL) fluid, ${ }^{30,32,42}$ lung tissue $^{30,32,43}$ or peripheral blood ${ }^{27-30,43-46}$ of patients with COPD compared to healthy controls. To date, chitotriosidase expression in induced sputum of COPD subjects has not previously been examined and only two studies assessed levels of YKL-40 in induced sputum of COPD patients, but without its parallel systemic evaluation. ${ }^{47,48}$

In this study, in order to investigate peripheral and local relations of chitinases and chitin-like proteins, we examined peripheral blood and sputum chitotriosidase and YKL-40 levels in healthy smokers and patients with COPD.

\section{Subjects and methods Subjects}

We studied a total of 70 volunteers including 40 COPD subjects and a control group consisting of 20 healthy smokers with a minimum of 10 pack-years smoking history, and 10 healthy never-smokers. Participants of this cohort have been examined previously in different research studies conducted at our institution. ${ }^{49,50}$ COPD was diagnosed according to the GOLD (2017) recommendations ${ }^{51}$ and defined as irreversible airflow obstruction with a post-bronchodilator
$\mathrm{FEV}_{1} / \mathrm{FVC}<0.7$. For healthy control subjects, only prebronchodilator spirometry was performed, and their prebronchodilator $\mathrm{FEV}_{1} / \mathrm{FVC}$ values were $>0.7$. All COPD subjects were in stable condition and were using regular inhaled medications. The study was approved by the ethics committee of the Medical University of Lodz and was performed according to the Declaration of Helsinki principles. All participants gave written informed consent before any study procedures.

\section{Methods}

All study participants underwent clinical assessments, including medical history, physical examination, spirometry, sputum induction, and peripheral blood sampling. Additionally, COPD patients assessed their symptoms with the modified Medical Research Council (mMRC) dyspnea scale, and COPD Assessment Test (CAT). Functional assessment included a six-minute walk test (6MWT). Using the collected data BODE (body mass index, airway obstruction, dyspnea, exercise capacity) index for each of the COPD patients was calculated. Serum and induced sputum supernatants were tested for YKL-40 concentrations and chitotriosidase activity and concentrations by means of ELISA and fluorometric assay, respectively. Chitotriosidase and YKL-40 mRNA expression in peripheral blood mononuclear cells (PBMC) and sputum cells were measured using quantitative polymerase chain reaction (qPCR).

\section{Spirometry}

Spirometry testing was performed using Lungtest 1000 spirometer (MES, Cracow, Poland) according to American Thoracic Society/European Respiratory Society (ATS/ERS) guidelines. ${ }^{52} \mathrm{FEV}_{1}, \mathrm{FVC}$, and $\mathrm{FEV}_{1} / \mathrm{FVC} \%$ were recorded.

\section{Induced sputum sampling procedure}

Sputum induction procedure was performed by a trained technician using the method described previously. ${ }^{49,53,54}$ Briefly, after salbutamol premedication $(400 \mu \mathrm{g})$, aerosols of hypertonic saline of 3\%, 4\%, and 5\% were each inhaled for 7 mins via ultrasonic nebulizer (Ultraneb 3000, Devilbiss, Somerset, PA, USA) with an output flow of 1 $\mathrm{mL} / \mathrm{min}$. All study participants were asked to cough into a plastic container after each of the hypertonic saline inhalations. For safety reasons, the procedure was monitored by spirometry at baseline and after each saline inhalation. Sputum induction was stopped if $\mathrm{FEV}_{1}$ fell by more than $20 \%$ from the baseline value. Fall in $\mathrm{FEV}_{1}$ of $10-19 \%$ was 
an indication to continue the procedure with the same concentration of hypertonic saline. Obtained sputum was selected from the expectorate and processed within $2 \mathrm{hrs}$ as described previously. ${ }^{54,55}$ Selected mucous plugs were processed using a two-step method. First mucous plugs were washed with a D-PBS, centrifuged, and then sputum supernatants were separated from cell pellets and stored at $-80^{\circ} \mathrm{C}$ until further evaluation. A wash step with D-PBS was followed by dithiothreitol step. The suspension was filtered, and a total cell count of leukocytes and viability was assessed. Cytospins were prepared from sputum cells and stained with Diff-Quick for differential cell counts analysis. Remaining sputum cells were subjected to measurements of CHIT1 and CHI3L1 mRNA expression and were kept at $-80^{\circ} \mathrm{C}$ until further processing.

\section{Blood samples processing}

Peripheral venous blood samples were withdrawn into lithium heparin tubes (BD Dickinson). Whole blood samples were diluted with McCoy 5A (Invitrogen), layered on Lymphoprep ( $\mathrm{d}=1.077 \mathrm{mg} / \mathrm{mL}$; Axis-Shield), and centrifuged at 2,200 rpm for $20 \mathrm{mins}$ at room temperature. PBMC were removed, washed with McCoy 5A (centrifugation at $1,500 \mathrm{rpm}$ for $10 \mathrm{mins}$ at $4^{\circ} \mathrm{C}$ ) and stored in $-80^{\circ} \mathrm{C}$ until gene expression profiling. Serum samples were kept in $-80^{\circ} \mathrm{C}$ until further processing using ELISA and fluorometric assay.

\section{Enzyme-linked immunosorbent assay}

YKL-40 concentration in serum and sputum supernatant was measured by MicroVue YKL-40 Enzyme Immunoassay Kit (Quidel Corporation, San Diego, CA, USA) according to the manufacturer's instructions. The limit of detection for the MicroVue YKL-40 EIA Kit was $5.4 \mathrm{ng} / \mathrm{mL}$. Each sample was tested in duplicate. Reported values are the average of two measurements. A coefficient of variation in all cases was $<5 \%$.

\section{Fluorometric assay}

Commercially available CycLex Chitotriosidase Fluorometric Assay Kit (Medical\&Biological Laboratories CO., LTD., Nagano, Japan) was used to measure chitotriosidase activity and concentration in serum and sputum supernatants. All assays were performed according to the manufacturer's instructions. Chitotriosidase activity was measured using 4-methylumbelliferyl- $\beta-N-N$ '-N"-triacetylchitotrioside (4-MUC) as a fluorogenic glycanase substrate with a final concentration of $0.02 \mathrm{mM}$. The enzyme reaction was initiated by the addition of $95 \mu \mathrm{L}$ of fluoro-substrate solution (4-MUC and assay buffer diluted in water) to $5 \mu \mathrm{L}$ of sample. 4-MUC was hydrolyzed by chitotriosidase present in the sample, producing 4-methylumbelliferone (4-MU) molecule. Fluorescence of 4-MU was measured for 50 mins at 4 mins intervals using VICTOR X4 Multilabel plate reader (Perkin Elmer Inc, Waltham, MA, USA) with excitation at $355 \mathrm{~nm}$ and emission at $460 \mathrm{~nm}$. Chitotriosidase activity was determined using the slope of the 4-MU standard curve as the conversion factor and was expressed as nanomoles of substrate hydrolyzed per milliliter per hour $(\mathrm{nmol} / \mathrm{mL} / \mathrm{h})$. Chitotriosidase concentrations were determined using the formula obtained from the standard curve generated by serial dilution of recombinant chitotriosidase (stock ca. $5 \mu \mathrm{g} / \mathrm{mL}$ ) and were expressed as nanograms per milliliter $(\mathrm{ng} / \mathrm{mL})$. Sputum supernatants samples did not require dilution while serum samples were diluted $5 \mathrm{x}$ (in $1 \mathrm{x}$ assay buffer). All measurements were read in 96-well microtiter plate (flat-bottomed, polystyrene, black) in a final volume of $100 \mu \mathrm{L}$. Reported values are the average of three measurements. A coefficient of variation in all cases was $<6 \%$.

\section{Gene expression analysis in PBMC and sputum cells \\ RNA isolation}

PBMC and sputum cells were resuspended in RNAlater (Thermofisher) and kept in $-80^{\circ} \mathrm{C}$ until RNA isolation. RNA isolation was performed using the mirVana ${ }^{\mathrm{TM}}$ miRNA Isolation Kit (Life Technologies, Carlsbad, CA, USA), according to the manufacturer's instructions. The quality and quantity of isolated RNA were spectrophotometrically assessed (Eppendorf BioPhotometrTM Plus, Eppendorf, Hamburg, Germany).

\section{RNA expression analysis}

Complementary DNA (cDNA) was transcribed from $100 \mathrm{ng}$ of total RNA, using a High-Capacity cDNA Reverse Transcription Kit (Applied Biosystems, Carlsbad, CA, USA) in a total volume of $20 \mu \mathrm{L}$, according to manufacturer's protocol. The relative expression analysis was performed in 7900HT Fast Real-Time PCR System (Applied Biosystems, Carlsbad, CA, USA) using TaqMan probes for the following genes: CHIT1 (Hs00185753_m1) and CHI3L1 (Hs01072228_m1) and ACTB (Hs99999903_m1) used as an endogenous control. The PCR mixture contained cDNA (1-100 ng), 20× TaqMan $^{\circledR}$ Gene Expression Assay, 2× KAPA PROBE Master Mix (2×) ABI Prism Kit (Kapa 
Biosystems, Wilmington, MA, USA), and RNase-free water in a total volume of $20 \mu \mathrm{L}$. The expression levels (relative quantification values - RQ) of the studied genes were calculated using the delta-delta $\mathrm{Ct}$ method formula used in order to calculate the relative fold gene expression of samples with the adjustment to the $\beta$-actin expression level and in relation to the expression level of calibrator (Human Lung Total RNA Ambion $^{\circledR}$ ), for which RQ value was equal to 1 .

\section{The mMRC dyspnea scale}

mMRC is a simple and widely used tool to evaluate dyspnea in a clinical setting. It is a five-level rating scale based on the individual patient's perception of dyspnea in daily activities. It consists of five statements which describe the entire range of dyspnea from none (Grade 0) to almost complete incapacity (Grade 4$){ }^{56}$

\section{The CAT}

CAT is a widely used, simple, and validated health status instrument dedicated for patients with COPD. This selfadministered questionnaire consists of eight items assessing various manifestations of COPD and the global impact of the disease on a patient's health status. ${ }^{57}$

\section{The 6MWT}

The 6MWT is used for evaluation of functional exercise capacity in patients with chronic respiratory conditions. In the present study, 6MWT was performed according to the methodology specified by the Polish Respiratory Society guidelines. ${ }^{58}$ Briefly, all COPD patients were instructed to walk as far as possible for 6 mins. The 6MWT was performed in $30 \mathrm{~m}$ long, flat and covered corridor, meterby-meter marked. When the test was finished, the distance covered by the subject was calculated and recorded.

\section{BODE index}

This multidimensional scoring system for COPD patients evaluates body mass index, a measure of airflow obstruction ( $\mathrm{FEV}_{1} \%$ predicted), dyspnea grading (mMRC scale), and exercise capacity (distance in 6MWT). This composite marker of disease takes into consideration the systemic nature of COPD and is used to predict long-term outcomes in this population. ${ }^{59}$

\section{Statistical analysis}

Data were analyzed using GraphPad Prism 5 (GraphPad Software, San Diego, CA, USA). Data are expressed as mean \pm standard error of the mean unless otherwise stated.
Normality of data distribution was tested with the ShapiroWilk test. Normally distributed data were analyzed using one-way ANOVA with a post hoc Tukey test. Not normally distributed data were analyzed with the Kruskal-Wallis test with the post hoc Dunn's test. Correlations were analyzed with the Pearson or Spearman correlation coefficient, where appropriate. Significance was accepted at $P<0.05$.

\section{Results}

\section{Characteristics of participants}

Summary of characteristics of study participants is shown in Table 1. Overall, COPD patients were older than the control group subjects and had a greater mean smoking exposure than healthy smokers $(P<0.05)$.

\section{Chitotriosidase peripheral blood and sputum levels \\ Peripheral blood}

Compared with healthy never-smokers $(131.9 \pm 19.87 \mathrm{ng} / \mathrm{mL})$, serum chitotriosidase concentration was numerically higher in healthy smokers $(185.3 \pm 20.43 \mathrm{ng} / \mathrm{mL})$ and COPD subjects $(178.4 \pm 17.99 \mathrm{ng} / \mathrm{mL})$. Similar pattern was noted for serum chitotriosidase activity $(3.32 \pm 0.55 \mathrm{nmol} / \mathrm{mL} / \mathrm{h}$ vs $4.81 \pm 0.57$ $\mathrm{nmol} / \mathrm{mL} / \mathrm{h}$ vs $4.62 \pm 0.36 \mathrm{nmol} / \mathrm{mL} / \mathrm{h})$. Chitotriosidase mRNA expression in PBMC was significantly elevated in COPD patients $(\mathrm{RQ}=4.57 \pm 0.87$ ) compared with healthy never-smokers $(\mathrm{RQ}=0.37 \pm 0.22, P<0.001)$. Graphic presentation of the results has been shown in Figure 1.

\section{Sputum}

Compared with healthy never-smokers $(24.37 \pm 5.70 \mathrm{ng} / \mathrm{mL})$, sputum chitotriosidase concentration was significantly elevated in COPD subjects $(80.86 \pm 11.78 \mathrm{ng} / \mathrm{mL}, P<0.01)$ and similar pattern was observed for sputum chitotriosidase activity $(0.97 \pm 0.19 \mathrm{nmol} / \mathrm{mL} / \mathrm{h}$ vs $3.31 \pm 0.45 \mathrm{nmol} / \mathrm{mL} / \mathrm{h}, P<0.001)$. Chitotriosidase mRNA expression in sputum was significantly elevated in healthy smokers $(\mathrm{RQ}=12.27 \pm 4.08)$ compared with healthy never-smokers $(\mathrm{RQ}=1.07 \pm 0.36, P<0.05)$. Graphic presentation of the results has been shown in Figure 1.

\section{YKL-40 peripheral blood and sputum levels Peripheral blood}

Compared with healthy never-smokers $(32.53 \pm 5.01 \mathrm{ng} / \mathrm{mL})$, serum YKL-40 concentration was greatest in COPD subjects $(99.12 \pm 12.08 \mathrm{ng} / \mathrm{mL}, P<0.001)$, but was also significantly elevated in healthy smokers $(80.32 \pm 14.51 \mathrm{ng} / \mathrm{mL}, P<0.01)$. Compared with healthy never-smokers $(R Q=0.02 \pm 0.01)$, YKL-40 mRNA expression in PBMC was significantly 
Table I Characteristics of study participants

\begin{tabular}{|c|c|c|c|}
\hline & Healthy never-smokers & Healthy smokers & COPD \\
\hline Number of subjects & 10 & 20 & 40 \\
\hline Sex (male/female) & $6 / 4$ & $11 / 9$ & $22 / 18$ \\
\hline Age (years) & $57.53 \pm 2.12$ & $57.85 \pm 2.00$ & $67.40 \pm 1.12^{\mathrm{a}, \mathrm{b}}$ \\
\hline Time since diagnosis (years) & $\mathrm{N} / \mathrm{A}$ & $\mathrm{N} / \mathrm{A}$ & $7.05 \pm 1.00$ \\
\hline Smoking exposure (pack-years) & $N / A$ & $32.14 \pm 2.96$ & $41.99 \pm 2.78^{\mathrm{b}}$ \\
\hline $\begin{array}{l}\text { Smoking status } \\
\text { (current smokers/ex-smokers) }\end{array}$ & $0 / 0$ & $20 / 0$ & $17 / 23$ \\
\hline FEV $(\%$ predicted $)$ & $109.4 \pm 2.77$ & $96.88 \pm 6.26$ & $61.98 \pm 2.76^{\mathrm{a}, \mathrm{b}}$ \\
\hline $\mathrm{FEV}_{\mathrm{l}} / \mathrm{FVC} \%$ & $80.39 \pm 1.34$ & $74.39 \pm 1.18$ & $52.49 \pm 1.57^{\mathrm{a}, \mathrm{b}}$ \\
\hline BMI $\left(\mathrm{kg} / \mathrm{m}^{2}\right)$ & $28.42 \pm 1.04$ & $27.72 \pm 0.68$ & $28.39 \pm 1.05$ \\
\hline 6MWT (m) & $\mathrm{N} / \mathrm{A}$ & N/A & $388.6 \pm 11.08$ \\
\hline CAT (score) & $N / A$ & $N / A$ & $15.8 \pm 1.18$ \\
\hline mMRC (median, min-max) & $\mathrm{N} / \mathrm{A}$ & N/A & I (0-3) \\
\hline BODE index (median, min-max) & $\mathrm{N} / \mathrm{A}$ & N/A & $I(0-6)$ \\
\hline Sputum macrophages (\%) & $65.69 \pm 3.76$ & $56.85 \pm 1.99$ & $44.70 \pm 4 I^{\mathrm{a}, \mathrm{b}}$ \\
\hline Sputum neutrophils (\%) & $18.89 \pm 3.77$ & $23.28 \pm 2.23$ & $37.40 \pm 4.93^{\mathrm{a}}$ \\
\hline Sputum lymphocytes (\%) & $6.43 \pm 0.84$ & $4.26 \pm 0.72$ & $6.60 \pm 1.99$ \\
\hline Sputum eosinophils (\%) & $0.89 \pm 0.28$ & $1.43 \pm 0.28$ & $2.93 \pm 0.95$ \\
\hline
\end{tabular}

Notes: ${ }^{a}$ COPD vs Healthy never-smokers, $P<0.05$; ${ }^{b} C O P D$ vs Healthy smokers, $P<0.05$. BODE index, BMI, airway obstruction, dyspnea, exercise capacity.

Abbreviations: BMI, body mass index; 6MWT, six-minute walk test; CAT, COPD Assessment Test; mMRC, modified Medical Research Council dyspnea scale.

elevated in both healthy smokers $(\mathrm{RQ}=1.36 \pm 0.38, P<0.0001)$ and COPD subjects $(\mathrm{RQ}=1.08 \pm 0.41, P<0.0001)$. Graphic presentation of the results has been shown in Figure 2.

\section{Sputum}

Sputum YKL-40 concentration was significantly elevated in COPD subjects compared with healthy never-smokers $(54.73 \pm 8.53 \mathrm{ng} / \mathrm{mL}$ vs $16.73 \pm 5.68 \mathrm{ng} / \mathrm{mL}, P<0.01)$. YKL40 sputum mRNA expression did not differ significantly between studied groups. Graphic presentation of the results has been shown in Figure 2.

\section{Chitotriosidase and YKL-40 peripheral blood and sputum levels in subgroups of COPD patients with and without}

\section{eosinophilic airway inflammation}

Additional analysis of COPD subjects based on sputum eosinophil count was performed. This led to a division of COPD cohort into a subgroup with eosinophilic inflammation (sputum eosinophil level $>3 \%$ ) and subgroup without eosinophilic inflammation (sputum eosinophil level $\leq 3 \%$ ). It was found that $25 \%$ of COPD subjects had sputum eosinophilia $>3 \%$ (mean sputum eosinophil percentage for this subgroup was $8.89 \pm 3.18 \%$ ).

No significant difference was noted in peripheral blood chitotriosidase concentration levels between the subgroup of COPD patients with and without sputum eosinophilic inflammation. Sputum chitotriosidase activity was significantly elevated $(3.86 \pm 0.57 \mathrm{nmol} / \mathrm{mL} / \mathrm{h})$ in the subgroup without sputum eosinophilic inflammation compared to those with a sputum eosinophil level $>3 \%$ $(1.67 \pm 0.29 \mathrm{nmol} / \mathrm{mL} / \mathrm{h}, P<0.05)$. Sputum chitotriosidase concentrations and mRNA expression levels did not differ significantly between both subgroups, however, a trend toward numerically higher levels in the subgroup without airway eosinophilia was noted, see Figure 3. No significant difference was observed in peripheral blood and sputum YKL-40 levels with regard to sputum eosinophil count in patients with COPD, see Figure 4.

\section{Chitotriosidase and YKL-40 peripheral blood and sputum levels in subgroups of COPD patients based on the disease exacerbation history}

Additional analysis of COPD subjects based on the exacerbation history, including any moderate and/or severe exacerbation in the past 12 months was performed. Of the 40 subjects studied, 13 had at least one COPD exacerbation and 27 subjects did not have disease exacerbation within previous 12 months. We have not found any significant differences in chitotriosidase concentration, activity, or mRNA expression 
Blood

A

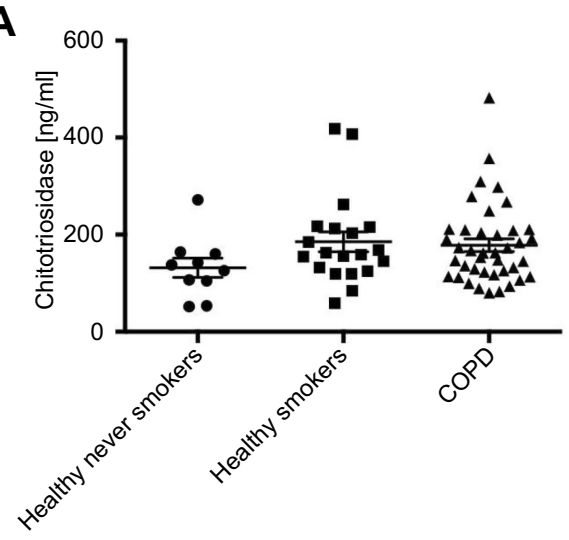

C

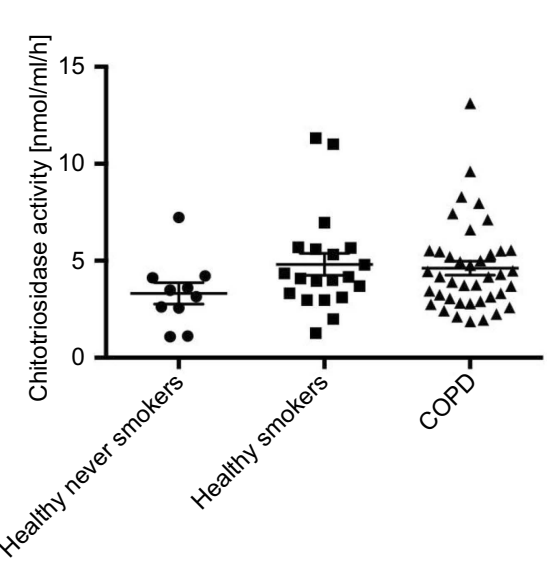

E

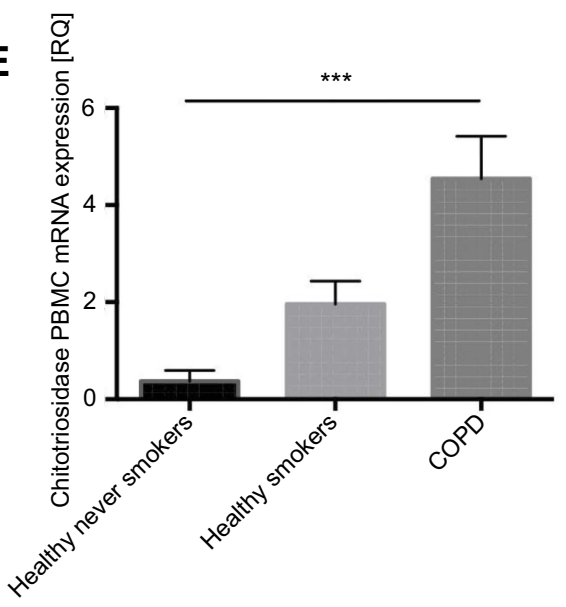

B

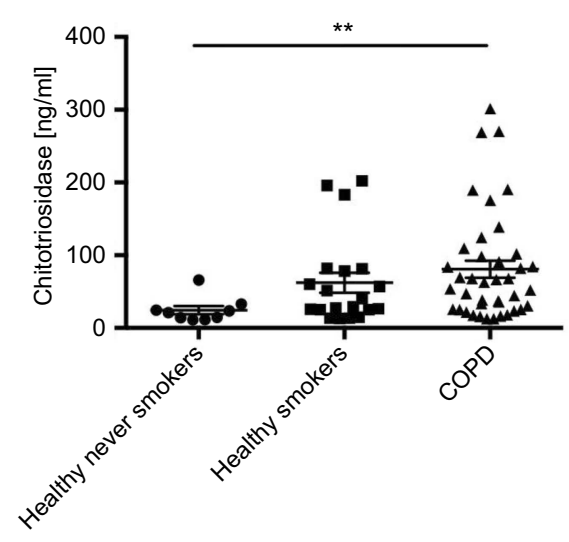

D
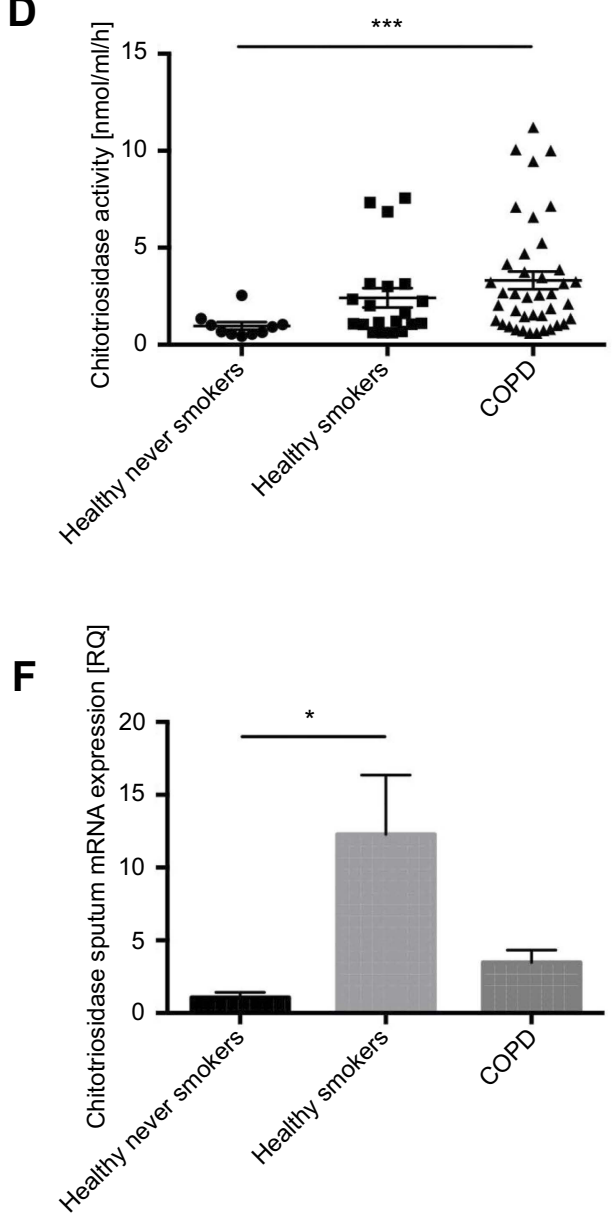

Figure I Chitotriosidase peripheral blood and sputum levels.

Notes: Panels showing: chitotriosidase concentration $(\mathbf{A})$ in peripheral blood, (B) in sputum; chitotriosidase activity (C) in peripheral blood, (D) in sputum; chitotriosidase mRNA expression (E) in peripheral blood, (F) in sputum. $* P<0.05 ; * * P<0.0$ I; $* * * P<0.001$.

Abbreviation: PBMC, peripheral blood mononuclear cells.

levels in peripheral blood and sputum between both subgroups, see Figure 5. YKL-40 sputum mRNA expression was significantly elevated $(\mathrm{RQ}=0.67 \pm 0.32)$ in the subgroup without exacerbation history compared to patients with exacerbation history in the past 12 months $(\mathrm{RQ}=0.12 \pm 0.05 ; P<0.05)$. A similar trend 

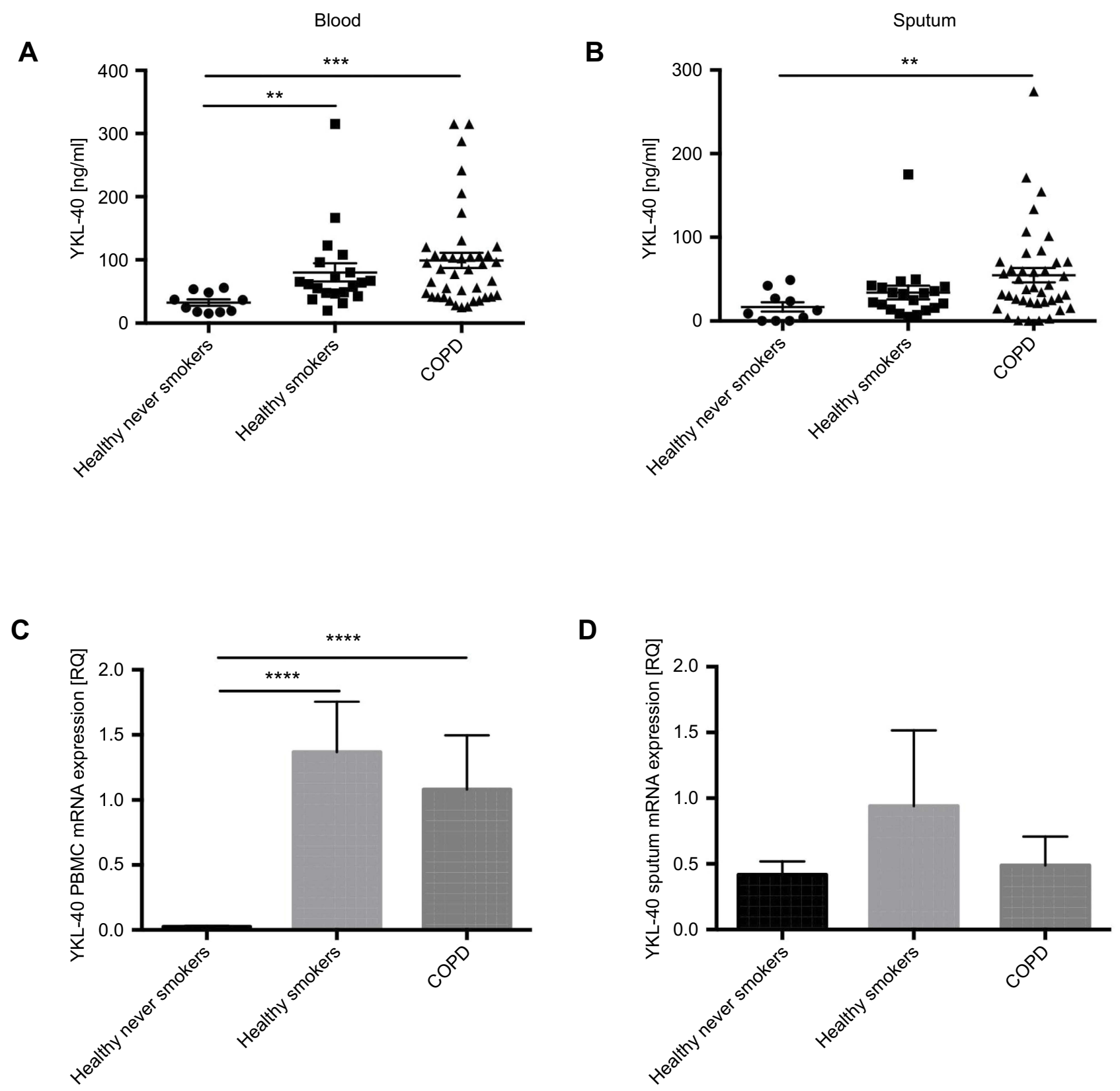

Figure 2 YKL-40 peripheral blood and sputum levels.

Notes: Panels showing: YKL-40 concentration (A) in peripheral blood, (B) in sputum; YKL-40 mRNA expression (C) in peripheral blood, (D) in sputum. $* * P<0.0$ I; $* * * P<0.001$; **** $P<0.0001$.

Abbreviation: PBMC, peripheral blood mononuclear cells.

for higher PBMC mRNA expression levels of YKL-40 was noted, however difference did not reach statistical significance. No significant difference was noted in peripheral blood or sputum YKL-40 concentration levels, see Figure 6. To further explore chitinases expression in relation to COPD exacerbations, we have analyzed COPD subjects based on the risk for future disease exacerbations. We have categorized patients according to GOLD guideline ${ }^{51}$ into low-risk subgroup (GOLD category $\mathrm{A}+\mathrm{B}$ ) and high-risk subgroup for future exacerbations (GOLD category $\mathrm{C}$ $+D)$. Of the 40 COPD patients studied, 31 were classified as GOLD category A+B (0-1 moderate exacerbation within previous 12 months) and 9 were classified as GOLD category $\mathrm{C}+\mathrm{D}(\geq 2$ moderate exacerbations and/or $\geq 1$ leading to hospital admission within previous 
Blood

A

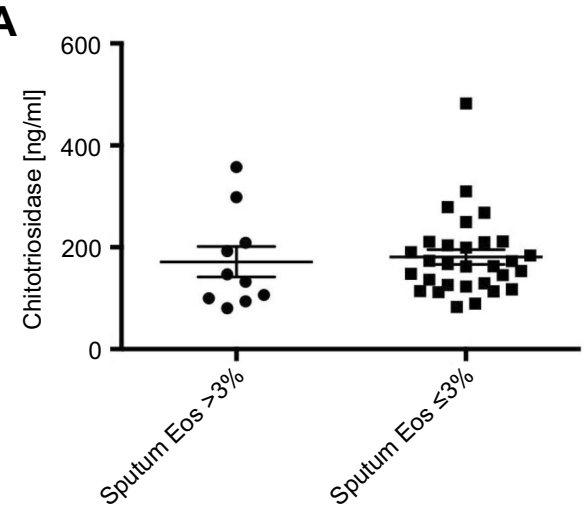

C

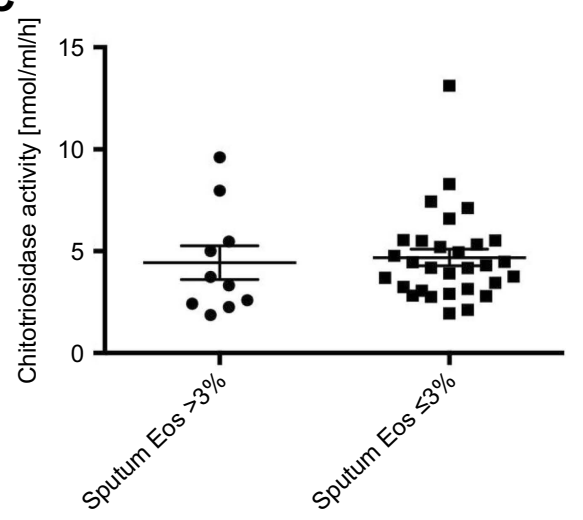

E

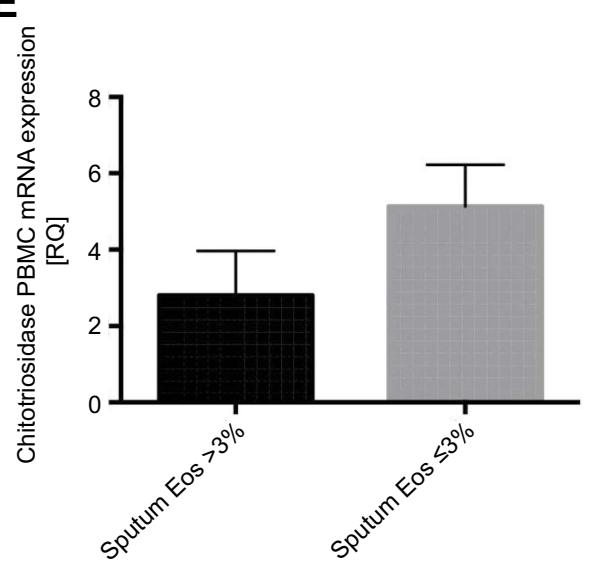

B

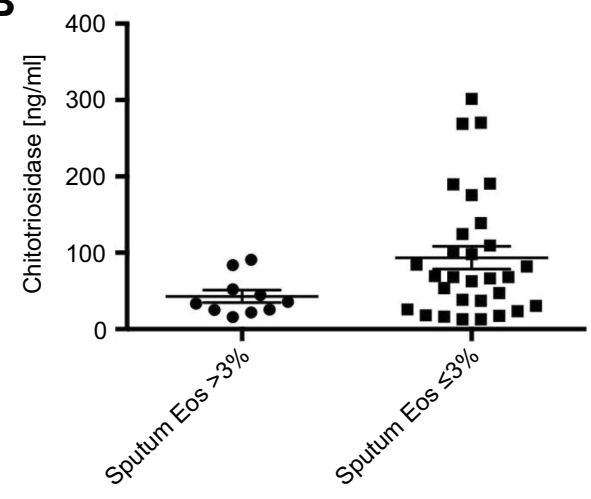

D

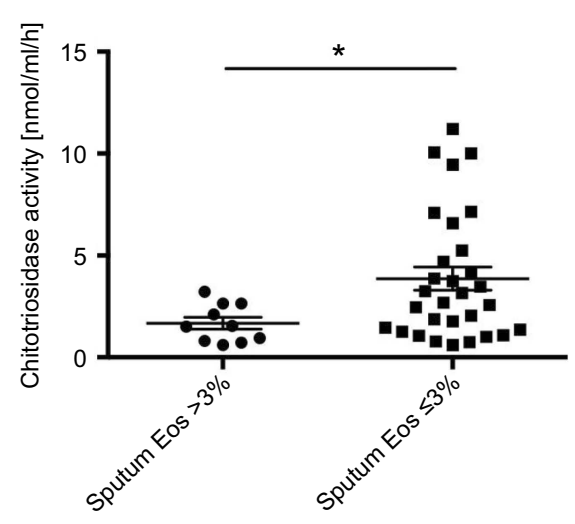

$\mathbf{F}$

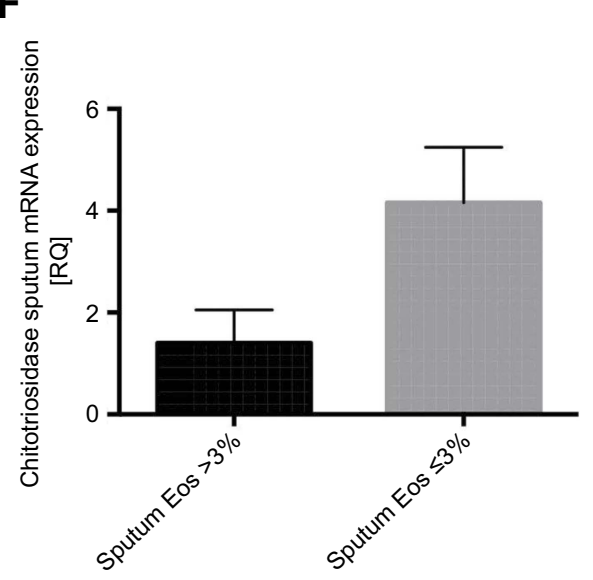

Figure 3 Chitotriosidase levels in COPD subjects with and without sputum eosinophilic inflammation.

Notes: Panels showing: chitotriosidase concentration (A) in peripheral blood, (B) in sputum; chitotriosidase activity (C) in peripheral blood, (D) in sputum; chitotriosidase mRNA expression (E) in peripheral blood, (F) in sputum. ${ }^{*} P<0.05$.

Abbreviations: PBMC, peripheral blood mononuclear cells; Eos, eosinophils.

12 months). Analysis of COPD subjects based on the risk for future exacerbations revealed significantly elevated sputum chitotriosidase concentration (107.8 $\pm 15.9 \mathrm{ng} / \mathrm{mL})$ and activity levels $(4.1 \pm 0.6 \mathrm{nmol} / \mathrm{mL} / \mathrm{h})$ 
Blood

A
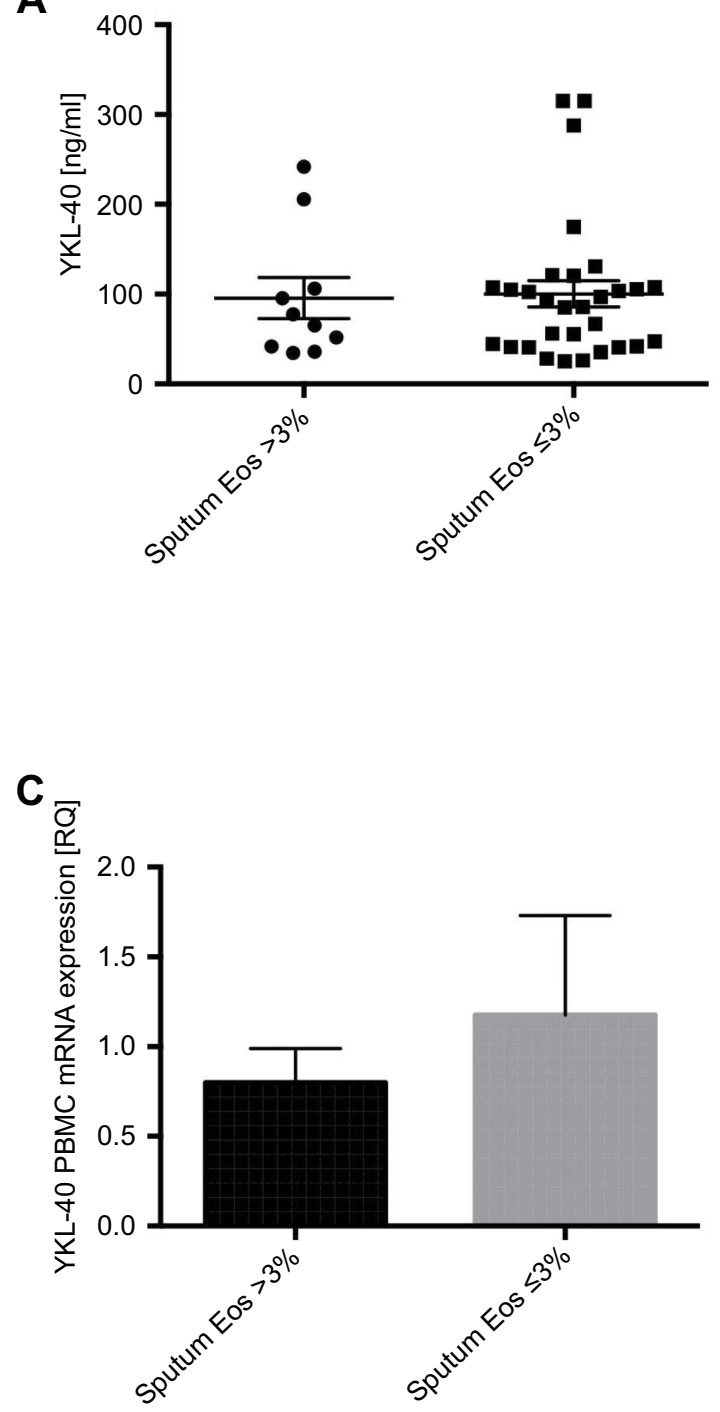

B

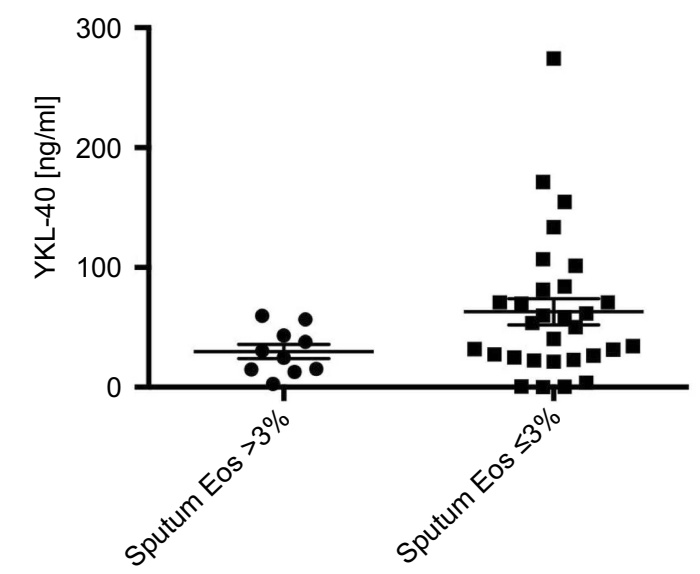

D

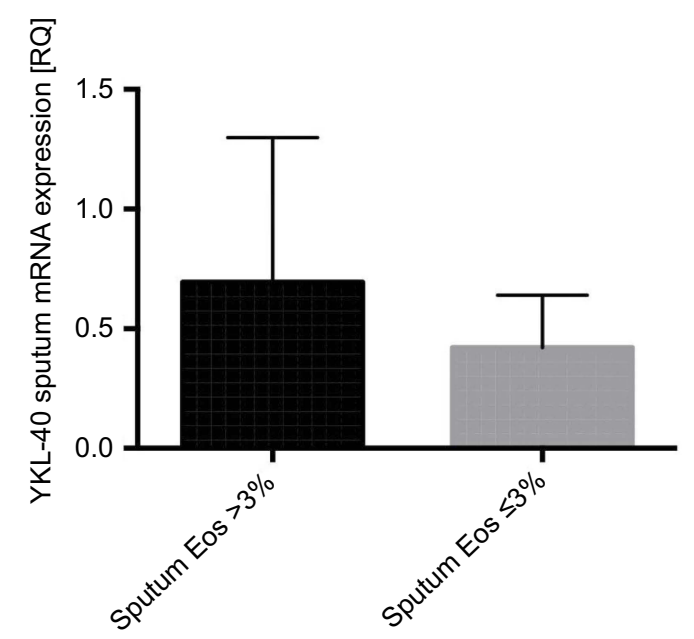

Figure 4 YKL-40 levels in COPD subjects with and without sputum eosinophilic inflammation.

Notes: Panels showing: YKL-40 concentration (A) in peripheral blood, (B) in sputum; YKL-40 mRNA expression (C) in peripheral blood, (D) in sputum. Abbreviations: PBMC, peripheral blood mononuclear cells; Eos, eosinophils.

in the high-risk subgroup compared with the low-risk subgroup $(80.4 \pm 15.3 \mathrm{ng} / \mathrm{mL}, P<0.05$ and $3.1 \pm 0.6 \mathrm{nmol} /$ $\mathrm{mL} / \mathrm{h}, P<0.05$, respectively). No significant difference was noted in sputum chitotriosidase mRNA expression levels. Chitotriosidase concentration, activity, and mRNA expression levels in peripheral blood did not differ significantly between both subgroups of patients, see Figure 7. YKL-40 sputum mRNA expression was significantly elevated $(\mathrm{RQ}=0.61 \pm 0.28)$ in the low-risk subgroup compared with the high-risk subgroup $(\mathrm{RQ}=0.06 \pm 0.02 ; \quad P<0.01)$. No significant difference was noted in peripheral blood and sputum YKL-40 levels as well as in PBMC mRNA expression between both subgroups of COPD patients, see Figure 8.

\section{Analysis of correlations between chitotriosidase and YKL-40 levels and clinical measures in patients with COPD Peripheral blood}

We found significant correlations between chitotriosidase PBMC mRNA expression levels and smoking exposure quantified in pack-years $(\mathrm{R}=0.31 ; P=0.04)$. YKL-40 serum concentration levels correlated with 

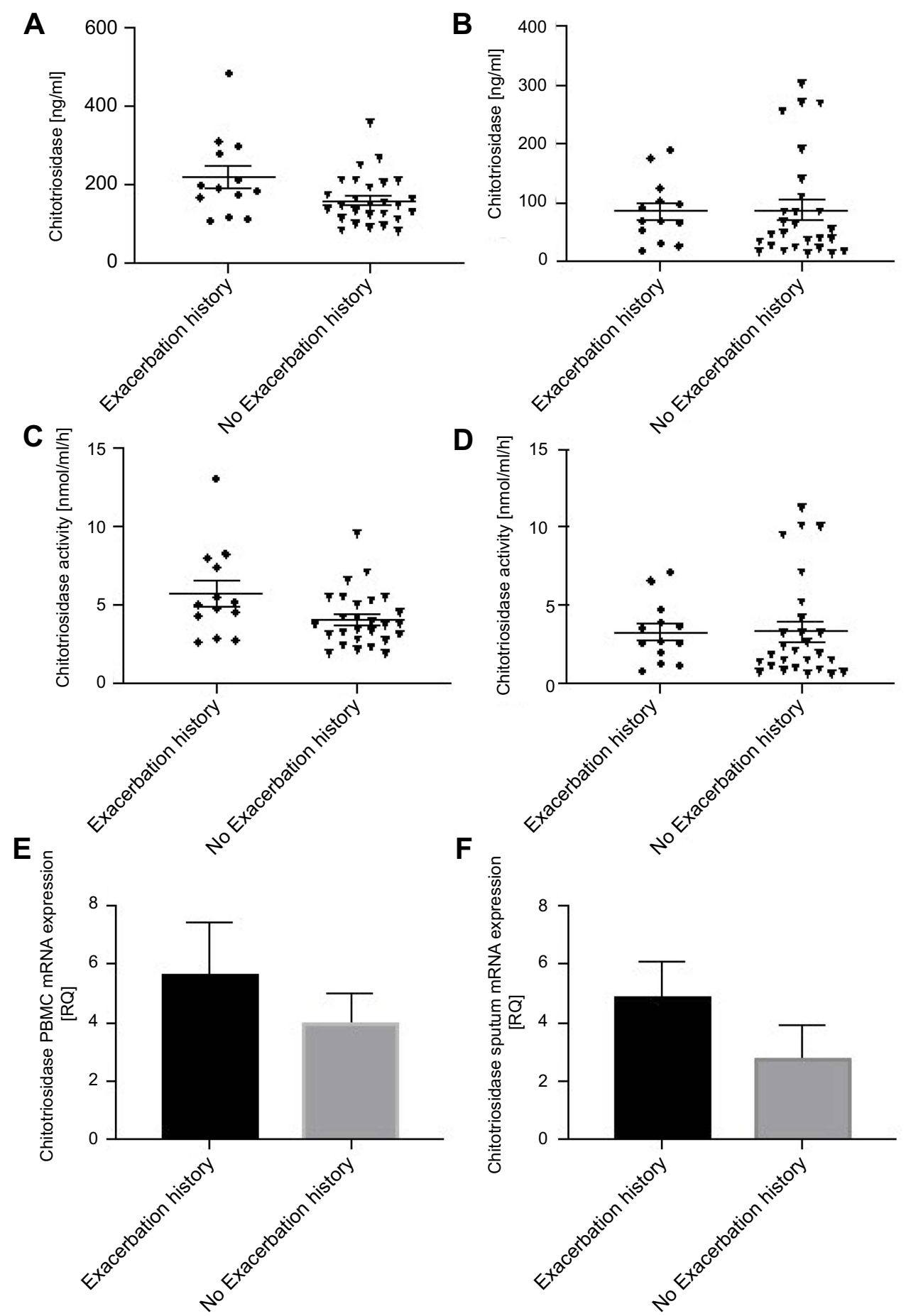

Figure 5 Chitotriosidase levels in COPD subjects with and without exacerbation history.

Notes: Panels showing: chitotriosidase concentration (A) in peripheral blood, (B) in sputum; chitotriosidase activity (C) in peripheral blood, (D) in sputum; chitotriosidase mRNA expression (E) in peripheral blood, (F) in sputum.

Abbreviation: PBMC, peripheral blood mononuclear cells.

sputum neutrophils cell counts $(\mathrm{R}=0.40 ; P=0.01)$ and YKL-40 PBMC mRNA expression levels correlated with time since diagnosis $(\mathrm{R}=0.34 ; P=0.03)$, as shown in Table 2. Graphical representation of the most relevant and significant correlations between chitotriosidase and YKL-40 peripheral blood levels and clinical measures in patients with COPD has been shown in Figure 9. 
Blood

A

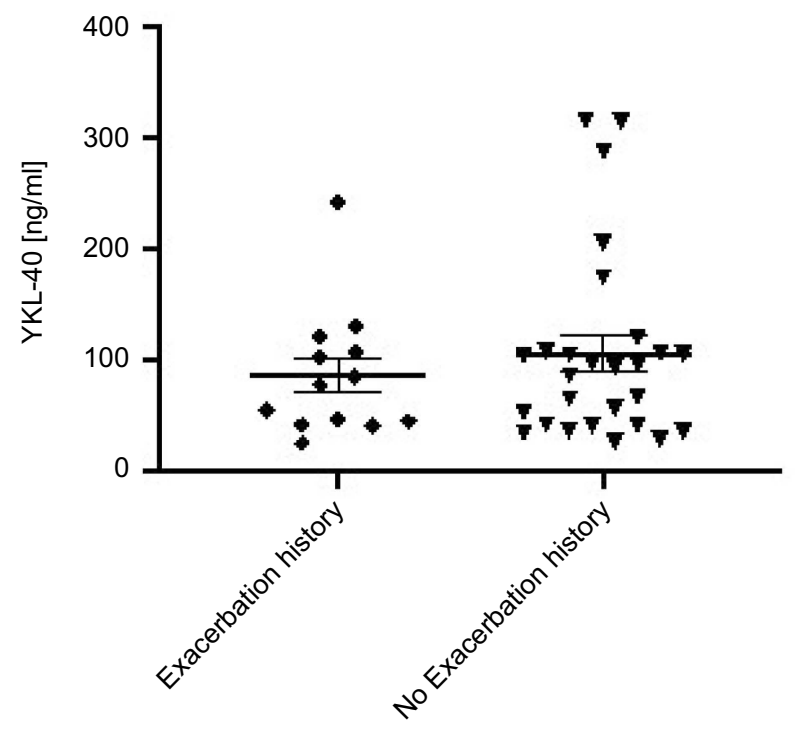

C

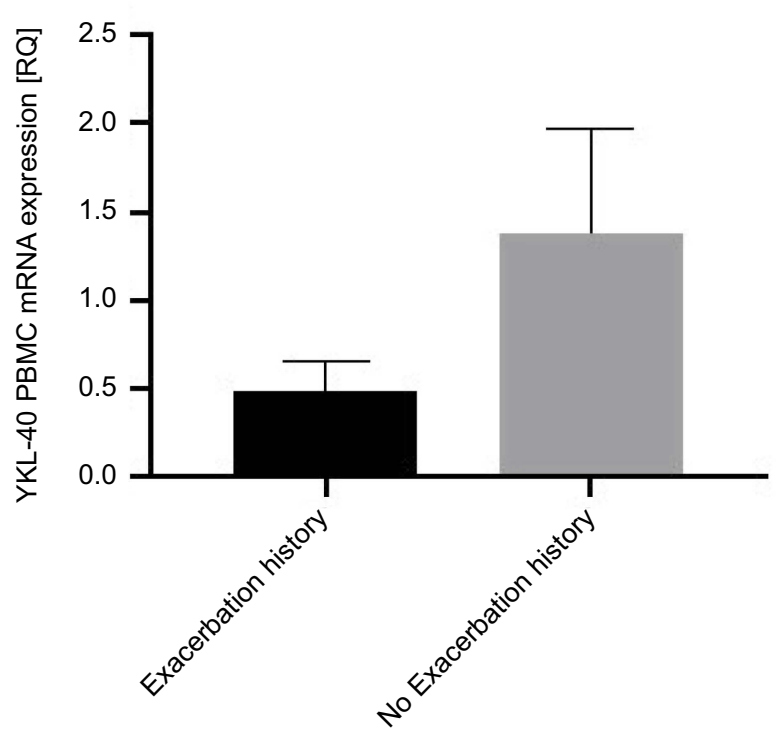

B

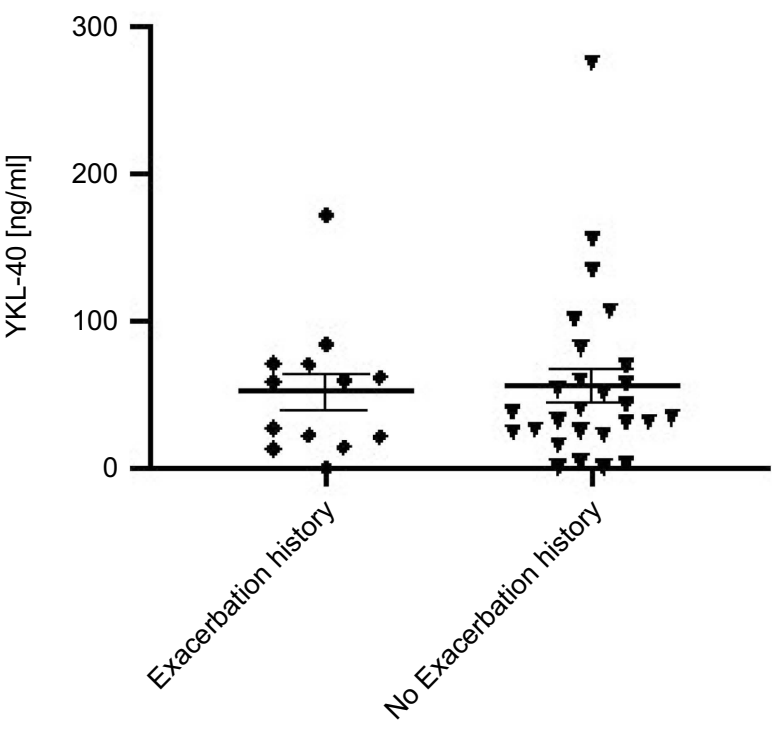

D

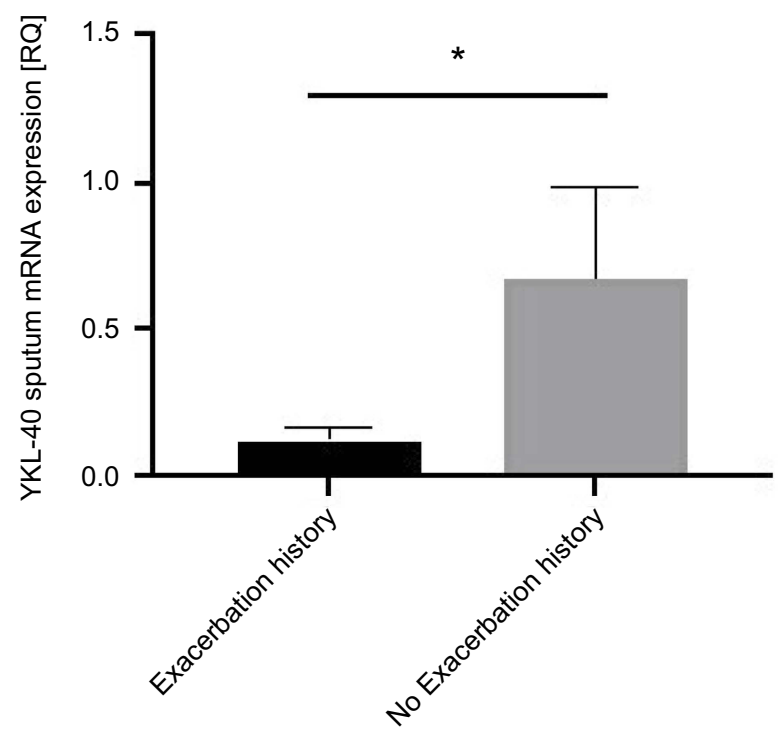

Figure 6 YKL-40 levels in COPD subjects with and without exacerbation history. Notes: Panels showing: YKL-40 concentration (A) in peripheral blood, (B) in sputum; YKL-40 mRNA expression (C) in peripheral blood, (D) in sputum. $* P<0.05$. Abbreviation: PBMC, peripheral blood mononuclear cells.

\section{Sputum}

We found significant positive correlations between chitotriosidase sputum concentrations and $\mathrm{FEV}_{1} \%$ of predicted value $(\mathrm{R}=0.36 ; P=0.02)$, as well as $\mathrm{FEV}_{1} / \mathrm{FVC} \%$ $(\mathrm{R}=0.31 ; P=0.049)$. Chitotriosidase sputum activity correlated negatively with the age of COPD patients
$(\mathrm{R}=-0.33 ; P=0.03)$. Significant correlations were also noted between sputum YKL-40 levels and the time since COPD diagnosis $(\mathrm{R}=0.34 ; P=0.03)$ as well as between sputum YKL-40 mRNA expression levels and sputum eosinophils cell counts $(\mathrm{R}=0.59 ; P<0.0001)$. All correlations between chitotriosidase and YKL-40 
Blood

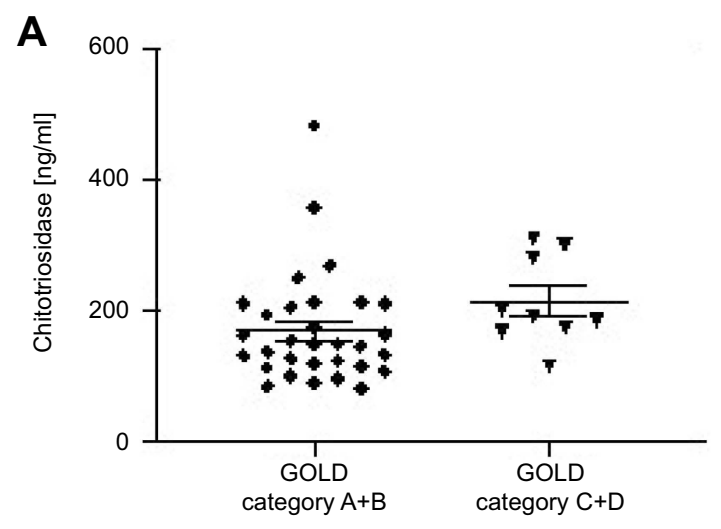

C

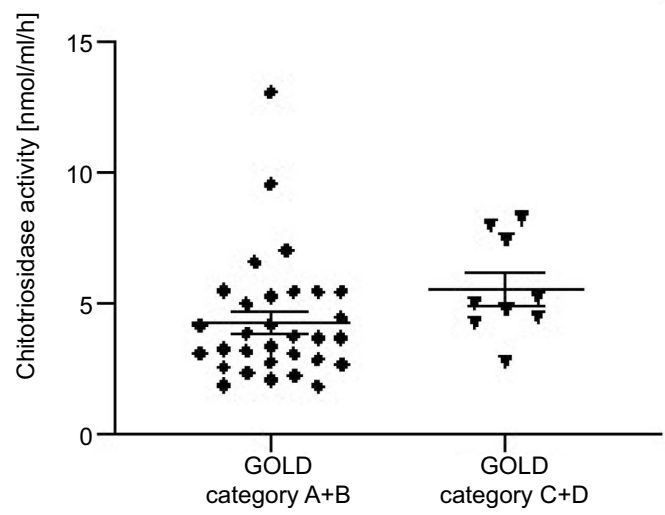

E

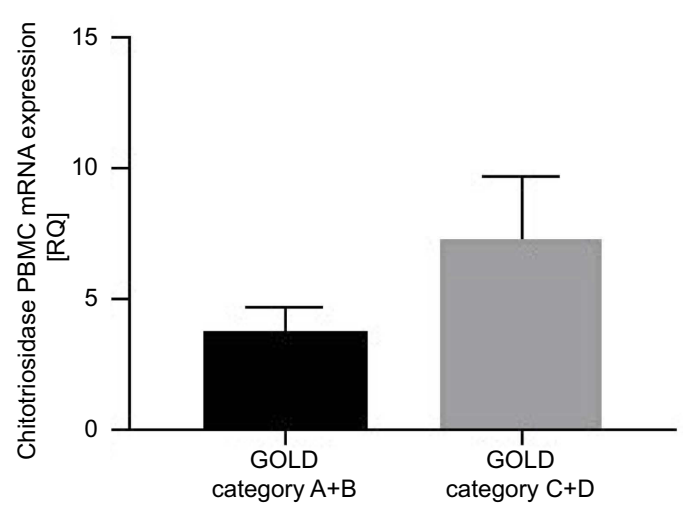

Sputum

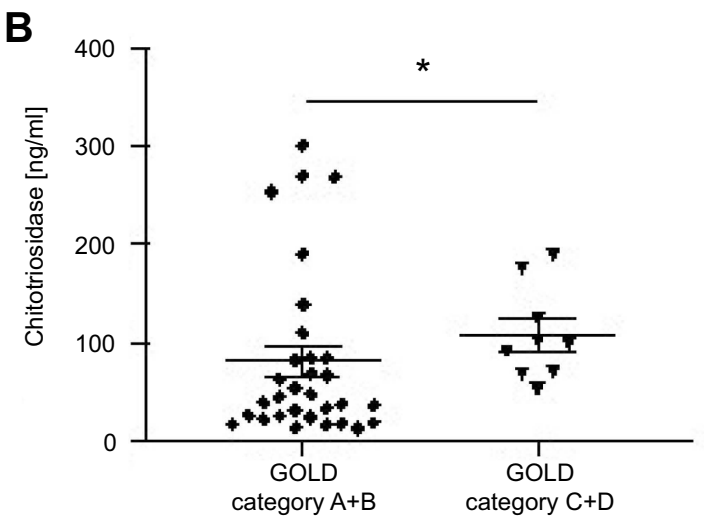

D

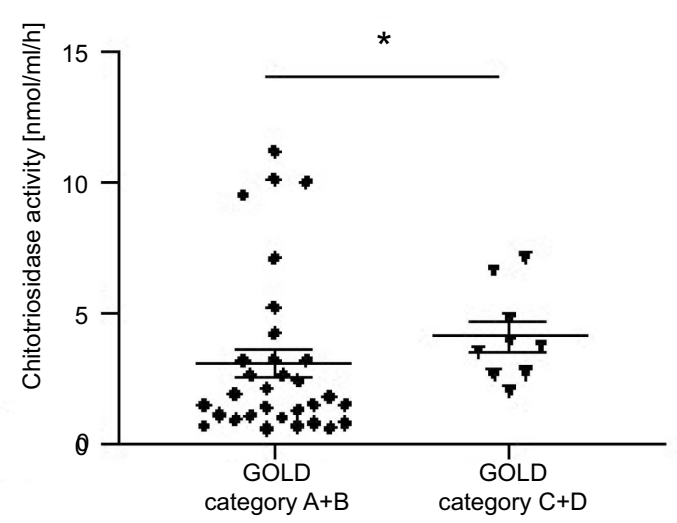

$\mathbf{F}$

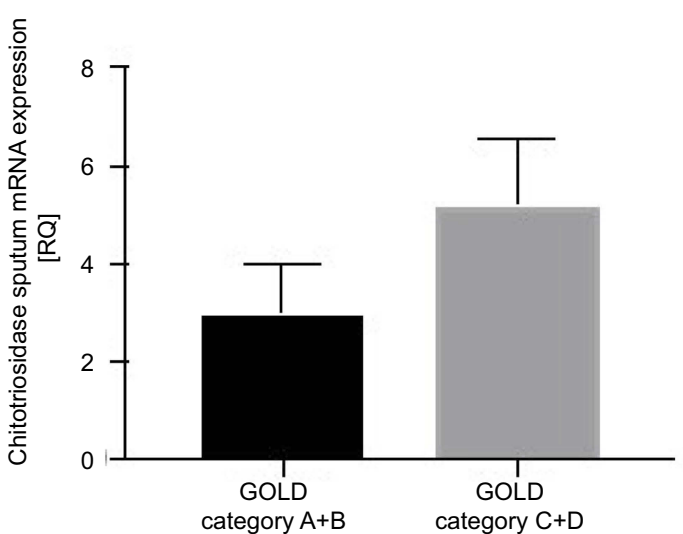

Figure 7 Chitotriosidase levels in COPD subjects with low risk (GOLD category A+B) and high risk (GOLD category C+D) for future exacerbations.

Notes: Panels showing: chitotriosidase concentration $(\mathbf{A})$ in peripheral blood, (B) in sputum; chitotriosidase activity (C) in peripheral blood, (D) in sputum; chitotriosidase mRNA expression $(\mathbf{E})$ in peripheral blood, $(\mathbf{F})$ in sputum. ${ }^{*} P<0.05$.

Abbreviation: PBMC, peripheral blood mononuclear cells.

sputum levels and clinical parameters of the COPD cohort are shown in Table 3. Graphical representation of the most relevant and significant correlations between chitotriosidase and YKL-40 sputum levels and clinical measures in patients with COPD has been shown in Figure 9. 

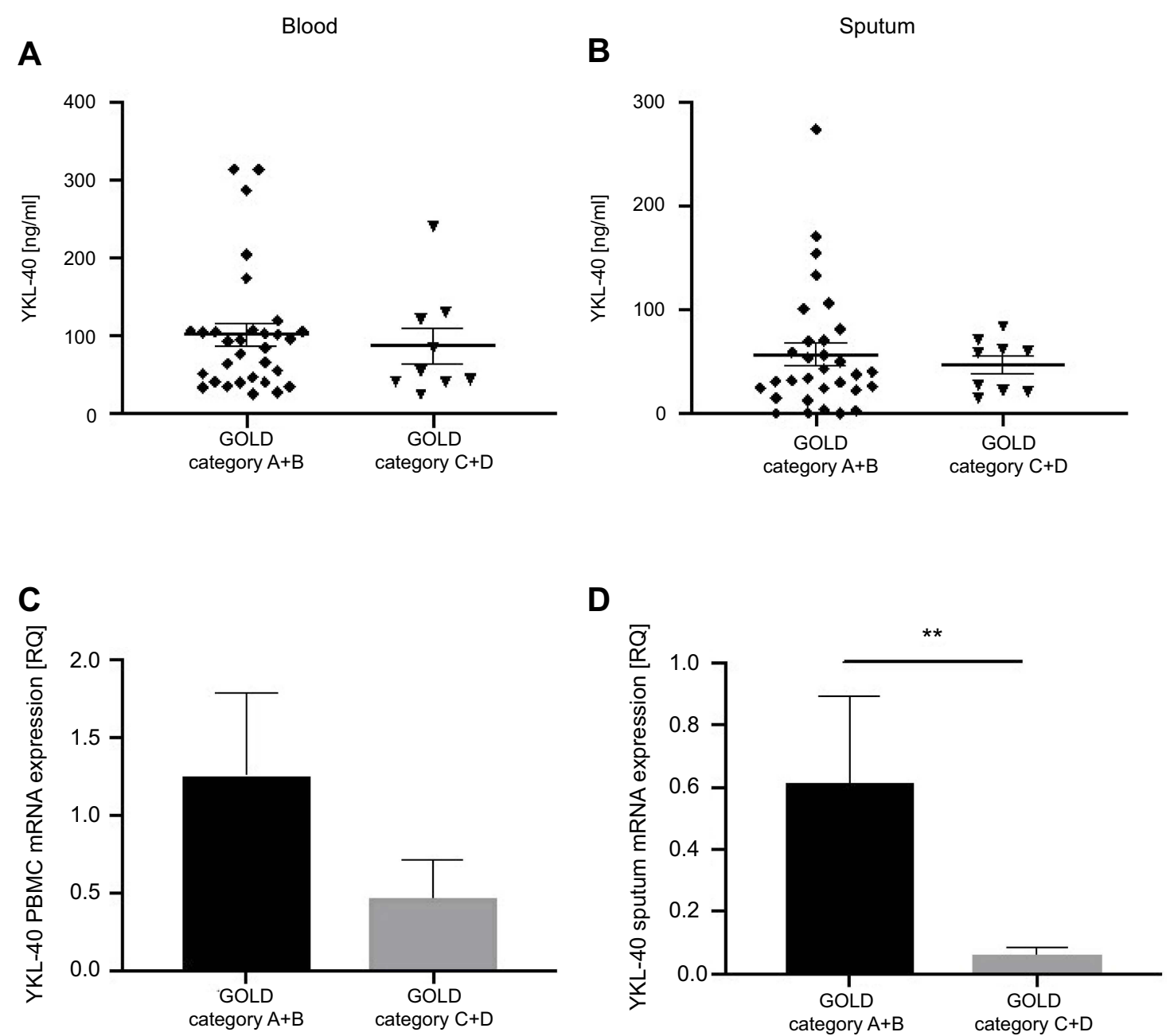

Figure 8 YKL-40 levels in COPD subjects with low risk (GOLD category A+B) and high risk (GOLD category C+D) for future exacerbations. Notes: Panels showing: YKL-40 concentration (A) in peripheral blood, (B) in sputum; YKL-40 mRNA expression (C) in peripheral blood, (D) in sputum. **P<0.0I. Abbreviation: PBMC, peripheral blood mononuclear cells.

\section{Analysis of correlations between chitotriosidase and YKL-40 peripheral blood levels and sputum levels in patients with COPD}

We did not find any significant associations of chitotriosidase and YKL-40 peripheral blood levels with sputum levels in COPD subjects (data not presented).

\section{Discussion}

To the best of our knowledge, no previous studies have been undertaken to evaluate in parallel chitotriosidase and YKL-40 protein, activity and gene expression levels in peripheral blood and sputum of patients with COPD. The main findings of the present study are that chitotriosidase and YKL-40 are overexpressed in peripheral blood and sputum of both healthy smokers and COPD patients compared to healthy control subjects, which may indicate smoking-related activation of macrophages, neutrophils, and epithelial cells. Interestingly, sputum chitotriosidase activity levels were higher in COPD patients without sputum eosinophilic inflammation than in COPD patients with sputum eosinophilia. Moreover, sputum chitotriosidase concentration and activity levels were elevated in COPD patients with high risk compared with patients with low risk for future exacerbation. YKL-40 expression levels in serum and sputum of COPD subjects correlate positively with disease duration. No associations were found between chitotriosidase or YKL-40 peripheral blood levels and sputum levels. Taken together we have demonstrated based on protein, activity and gene expression data, that both chitotriosidase and YKL-40 may serve as valuable 
Table 2 Analysis of correlations between chitotriosidase and YKL-40 peripheral blood levels and clinical parameters in patients with COPD

\begin{tabular}{|c|c|c|c|c|c|}
\hline & $\begin{array}{l}\text { Chitotriosidase } \\
\text { serum } \\
\text { concentration }\end{array}$ & $\begin{array}{l}\text { Chitotriosidase } \\
\text { serum activity }\end{array}$ & $\begin{array}{l}\text { Chitotriosidase } \\
\text { PBMC mRNA } \\
\text { expression }\end{array}$ & $\begin{array}{l}\text { YKL-40 serum } \\
\text { concentration }\end{array}$ & $\begin{array}{l}\text { YKL-40 PBMC } \\
\text { mRNA } \\
\text { expression }\end{array}$ \\
\hline Age & $\begin{array}{l}R=-0.10 \\
P=0.50\end{array}$ & $\begin{array}{l}R=-0.19 \\
P=0.22\end{array}$ & $\begin{array}{l}R=-0.1 I \\
P=0.48\end{array}$ & $\begin{array}{l}R=0.14 \\
P=0.37\end{array}$ & $\begin{array}{l}R=0.04 \\
P=0.8 I\end{array}$ \\
\hline Time since diagnosis & $\begin{array}{l}R=-0.10 \\
P=0.50\end{array}$ & $\begin{array}{l}R=-0.19 \\
P=0.21\end{array}$ & $\begin{array}{l}R=-0.27 \\
P=0.09\end{array}$ & $\begin{array}{l}R=0.14 \\
P=0.37\end{array}$ & $\begin{array}{l}R=0.34 \\
P=0.03\end{array}$ \\
\hline Pack-years & $\begin{array}{l}R=0.04 \\
P=0.76\end{array}$ & $\begin{array}{l}R=0.01 \\
P=0.96\end{array}$ & $\begin{array}{l}R=0.3 \mathrm{I} \\
P=0.04\end{array}$ & $\begin{array}{l}R=-0.02 \\
P=0.88\end{array}$ & $\begin{array}{l}R=0.17 \\
P=0.27\end{array}$ \\
\hline $\mathrm{FEV}_{1} \%$ predicted & $\begin{array}{l}R=0.00 \\
P=0.99\end{array}$ & $\begin{array}{l}R=-0.00 \\
P=0.97\end{array}$ & $\begin{array}{l}\mathrm{R}=0.0 \mathrm{I} \\
P=0.93\end{array}$ & $\begin{array}{l}\mathrm{R}=0.00 \\
P=0.99\end{array}$ & $\begin{array}{l}R=-0.12 \\
P=0.43\end{array}$ \\
\hline $\mathrm{FEV}_{1} / \mathrm{FVC} \%$ & $\begin{array}{l}R=0.06 \\
P=0.67\end{array}$ & $\begin{array}{l}R=0.16 \\
P=0.32\end{array}$ & $\begin{array}{l}R=-0.1 I \\
P=0.48\end{array}$ & $\begin{array}{l}R=-0.07 \\
P=0.64\end{array}$ & $\begin{array}{l}R=0.10 \\
P=0.53\end{array}$ \\
\hline BMI & $\begin{array}{l}R=-0.21 \\
P=0.19\end{array}$ & $\begin{array}{l}R=-0.25 \\
P=0.1 I\end{array}$ & $\begin{array}{l}R=0.04 \\
P=0.77\end{array}$ & $\begin{array}{l}R=-0.09 \\
P=0.56\end{array}$ & $\begin{array}{l}R=0.05 \\
P=0.74\end{array}$ \\
\hline CAT & $\begin{array}{l}R=-0.18 \\
P=0.25\end{array}$ & $\begin{array}{l}R=-0.16 \\
P=0.32\end{array}$ & $\begin{array}{l}R=0.02 \\
P=0.87\end{array}$ & $\begin{array}{l}R=-0.27 \\
P=0.08\end{array}$ & $\begin{array}{l}R=-0.17 \\
P=0.26\end{array}$ \\
\hline $\mathrm{mMRC}$ & $\begin{array}{l}R=-0.16 \\
P=0.29\end{array}$ & $\begin{array}{l}R=-0.22 \\
P=0.16\end{array}$ & $\begin{array}{l}R=0.00 \\
P=0.96\end{array}$ & $\begin{array}{l}R=-0.09 \\
P=0.56\end{array}$ & $\begin{array}{l}R=-0.24 \\
P=0.12\end{array}$ \\
\hline 6MWT & $\begin{array}{l}R=0.07 \\
P=0.63\end{array}$ & $\begin{array}{l}\mathrm{R}=0.05 \\
P=0.73\end{array}$ & $\begin{array}{l}\mathrm{R}=0.08 \\
P=0.59\end{array}$ & $\begin{array}{l}R=0.02 \\
P=0.86\end{array}$ & $\begin{array}{l}R=0.05 \\
P=0.74\end{array}$ \\
\hline BODE & $\begin{array}{l}R=-0.04 \\
P=0.78\end{array}$ & $\begin{array}{l}\mathrm{R}=0.0 \mathrm{I} \\
P=0.96\end{array}$ & $\begin{array}{l}R=-0.10 \\
P=0.52\end{array}$ & $\begin{array}{l}R=0.09 \\
P=0.57\end{array}$ & $\begin{array}{l}R=0.1 I \\
P=0.46\end{array}$ \\
\hline Sputum macrophages, \% & $\begin{array}{l}R=-0.07 \\
P=0.63\end{array}$ & $\begin{array}{l}R=0.06 \\
P=0.67\end{array}$ & $\begin{array}{l}R=0.00 \\
P=0.98\end{array}$ & $\begin{array}{l}R=-0.26 \\
P=0.09\end{array}$ & $\begin{array}{l}R=-0.07 \\
P=0.63\end{array}$ \\
\hline Sputum neutrophils, \% & $\begin{array}{l}R=0.19 \\
P=0.22\end{array}$ & $\begin{array}{l}\mathrm{R}=0.00 \\
P=0.99\end{array}$ & $\begin{array}{l}R=0.11 \\
P=0.49\end{array}$ & $\begin{array}{l}R=0.40 \\
P=0.01\end{array}$ & $\begin{array}{l}R=0.22 \\
P=0.16\end{array}$ \\
\hline Sputum lymphocytes, \% & $\begin{array}{l}R=-0.00 \\
P=0.98\end{array}$ & $\begin{array}{l}R=-0.03 \\
P=0.82\end{array}$ & $\begin{array}{l}R=-0.06 \\
P=0.69\end{array}$ & $\begin{array}{l}R=-0.28 \\
P=0.07\end{array}$ & $\begin{array}{l}R=-0.12 \\
P=0.46\end{array}$ \\
\hline Sputum eosinophils, \% & $\begin{array}{l}R=-0.12 \\
P=0.45\end{array}$ & $\begin{array}{l}R=0.07 \\
P=0.66\end{array}$ & $\begin{array}{l}R=-0.06 \\
P=0.72\end{array}$ & $\begin{array}{l}R=0.12 \\
P=0.42\end{array}$ & $\begin{array}{l}R=-0.06 \\
P=0.72\end{array}$ \\
\hline
\end{tabular}

Notes: BODE index, BMI, airway obstruction, dyspnea, exercise capacity.

Abbreviations: PBMC, peripheral blood mononuclear cells; BMI, body mass index CAT, COPD Assessment Test; mMRC, modified Medical Research Council dyspnea scale; 6MWT, six-minute walk test.

COPD biomarkers of inflammation and remodeling for systemic and local airway compartment studies. These findings add new evidence to the growing body of literature on the role of chitinases and chitin-like proteins in the pathophysiology of COPD.

Chitin is the second most abundant natural carbohydrate polymer after cellulose. It is an essential structural component of bacteria, fungi, and arthropods, including crustaceans, insects, mollusks, and nematodes. ${ }^{1}$ Those species have numerous genes encoding hydrolases with chitinolytic activity termed chitinases, permitting the chitin metabolism required for their growth and development. Surprisingly, although true chitinases are found, chitin or its synthases have not been detected in mammals. Chitinases are the enzymes that digest the chitin polymer and human subjects have two chitinases encoded in their genome, particularly chitotriosidase (CHIT1) and acidic mammalian chitinase (AMCase). Mammalian chitinases belong to the 18 glycosyl 


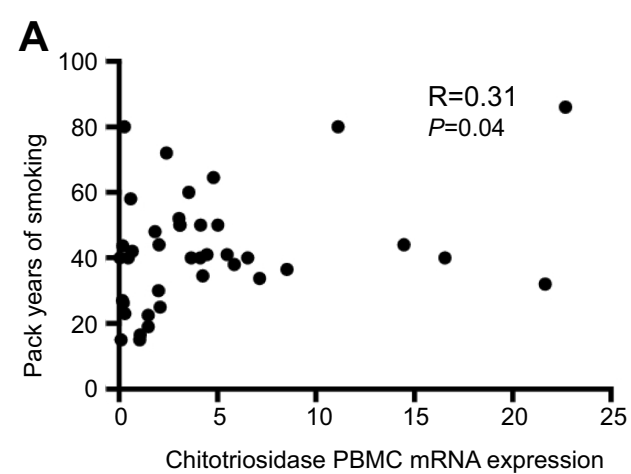

C

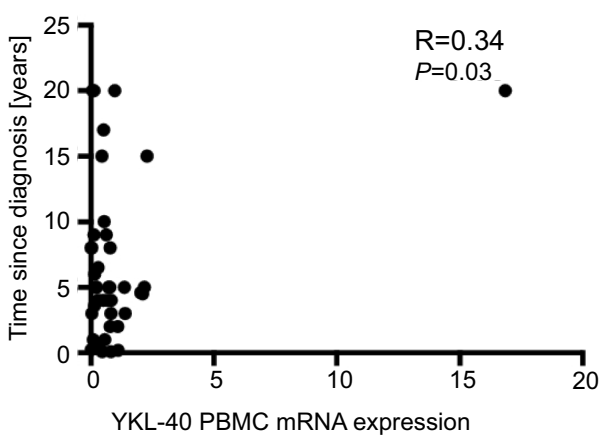

E

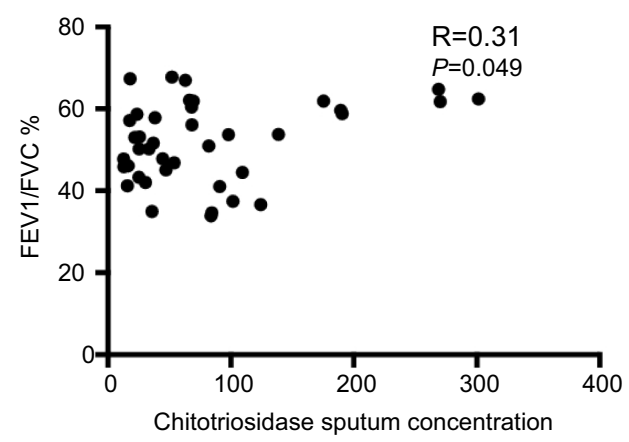

G

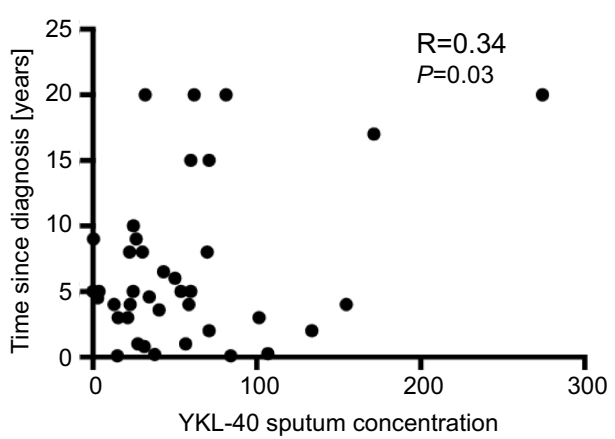

B

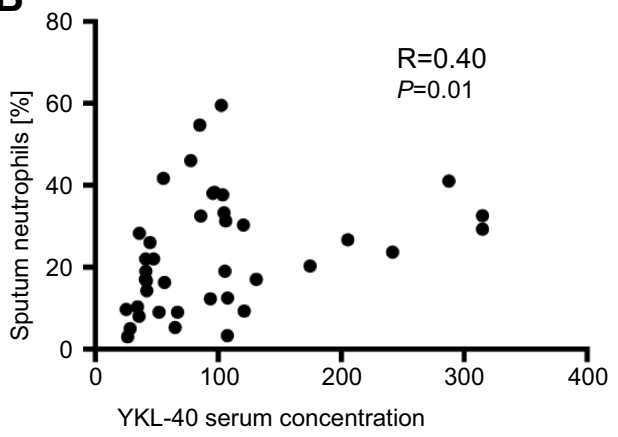

D

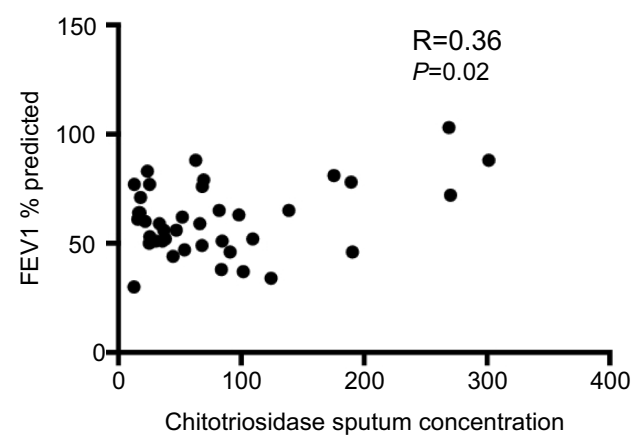

$\mathbf{F}$

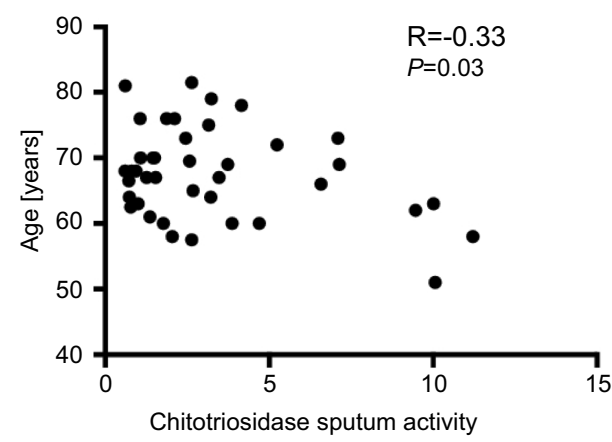

H

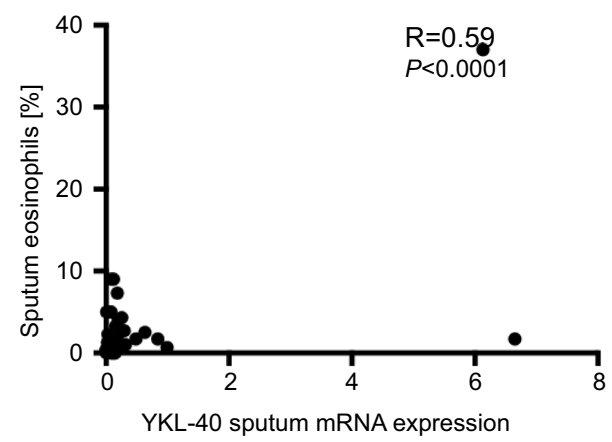

Figure 9 Graphical representation of the most relevant and significant correlations of chitotriosidase and YKL-40 peripheral blood levels (A-C) and sputum levels (D-H) with clinical measures in patients with COPD.

Notes: Panels showing correlation between: (A) chitotriosidase PBMC mRNA expression and pack-years of smoking, (B) YKL-40 serum concentration and sputum neutrophils, (C) YKL-40 PBMC mRNA expression and time since diagnosis, (D) chitotriosidase sputum concentration and $\mathrm{FEV}$, $\%$ predicted, (E) chitotriosidase sputum concentration and $\mathrm{FEV}_{\mathrm{I}} / \mathrm{FVC} \%$, (F) chitotriosidase sputum activity and age, (G) YKL-40 sputum concentration and time since diagnosis, (H) YKL-40 sputum mRNA expression and sputum eosinophils. 
Table 3 Analysis of correlations between chitotriosidase and YKL-40 sputum levels and clinical parameters in patients with COPD

\begin{tabular}{|c|c|c|c|c|c|}
\hline & $\begin{array}{l}\text { Chitotriosidase } \\
\text { sputum } \\
\text { concentration }\end{array}$ & $\begin{array}{l}\text { Chitotriosidase } \\
\text { sputum activity }\end{array}$ & $\begin{array}{l}\text { Chitotriosidase spu- } \\
\text { tum mRNA } \\
\text { expression }\end{array}$ & $\begin{array}{l}\text { YKL-40 spu- } \\
\text { tum } \\
\text { concentration }\end{array}$ & $\begin{array}{l}\text { YKL-40 sputum } \\
\text { mRNA } \\
\text { expression }\end{array}$ \\
\hline Age & $\begin{array}{l}R=-0.28 \\
P=0.07\end{array}$ & $\begin{array}{l}R=-0.33 \\
P=0.03\end{array}$ & $\begin{array}{l}R=-0.08 \\
P=0.60\end{array}$ & $\begin{array}{l}R=0.03 \\
P=0.82\end{array}$ & $\begin{array}{l}R=0.14 \\
P=0.39\end{array}$ \\
\hline Time since diagnosis & $\begin{array}{l}R=-0.11 \\
P=0.48\end{array}$ & $\begin{array}{l}R=0.25 \\
P=0.11\end{array}$ & $\begin{array}{l}R=-0.08 \\
P=0.61\end{array}$ & $\begin{array}{l}R=0.34 \\
P=0.03\end{array}$ & $\begin{array}{l}R=0.25 \\
P=0.11\end{array}$ \\
\hline Pack-years & $\begin{array}{l}R=-0.19 \\
P=0.23\end{array}$ & $\begin{array}{l}R=-0.01 \\
P=0.94\end{array}$ & $\begin{array}{l}R=-0.03 \\
P=0.80\end{array}$ & $\begin{array}{l}R=0.09 \\
P=0.55\end{array}$ & $\begin{array}{l}R=0.06 \\
P=0.67\end{array}$ \\
\hline $\mathrm{FEV}_{1} \%$ predicted & $\begin{array}{l}R=0.36 \\
P=0.02\end{array}$ & $\begin{array}{l}R=0.16 \\
P=0.31\end{array}$ & $\begin{array}{l}R=-0.04 \\
P=0.79\end{array}$ & $\begin{array}{l}R=-0.07 \\
P=0.65\end{array}$ & $\begin{array}{l}R=-0.14 \\
P=0.36\end{array}$ \\
\hline $\mathrm{FEV}_{1} / \mathrm{FVC} \%$ & $\begin{array}{l}R=0.31 \\
P=0.049\end{array}$ & $\begin{array}{l}R=0.03 \\
P=0.85\end{array}$ & $\begin{array}{l}R=-0.09 \\
P=0.57\end{array}$ & $\begin{array}{l}R=0.17 \\
P=0.27\end{array}$ & $\begin{array}{l}R=-0.06 \\
P=0.68\end{array}$ \\
\hline BMI & $\begin{array}{l}R=-0.25 \\
P=0.10\end{array}$ & $\begin{array}{l}R=-0.08 \\
P=0.59\end{array}$ & $\begin{array}{l}R=0.00 \\
P=0.97\end{array}$ & $\begin{array}{l}R=-0.10 \\
P=0.53\end{array}$ & $\begin{array}{l}R=0.10 \\
P=0.5 I\end{array}$ \\
\hline CAT & $\begin{array}{l}R=-0.14 \\
P=0.36\end{array}$ & $\begin{array}{l}R=0.25 \\
P=0.11\end{array}$ & $\begin{array}{l}R=0.02 \\
P=0.87\end{array}$ & $\begin{array}{l}R=0.03 \\
P=0.84\end{array}$ & $\begin{array}{l}R=-0.14 \\
P=0.37\end{array}$ \\
\hline $\mathrm{mMRC}$ & $\begin{array}{l}R=-0.25 \\
P=0.11\end{array}$ & $\begin{array}{l}R=0.25 \\
P=0.11\end{array}$ & $\begin{array}{l}R=0.03 \\
P=0.84\end{array}$ & $\begin{array}{l}R=-0.26 \\
P=0.09\end{array}$ & $\begin{array}{l}R=0.17 \\
P=0.27\end{array}$ \\
\hline 6MWT & $\begin{array}{l}R=0.05 \\
P=0.7 I\end{array}$ & $\begin{array}{l}R=-0.27 \\
P=0.09\end{array}$ & $\begin{array}{l}R=0.12 \\
P=0.44\end{array}$ & $\begin{array}{l}R=0.04 \\
P=0.75\end{array}$ & $\begin{array}{l}R=-0.24 \\
P=0.12\end{array}$ \\
\hline BODE & $\begin{array}{l}R=-0.17 \\
P=0.27\end{array}$ & $\begin{array}{l}R=0.06 \\
P=0.68\end{array}$ & $\begin{array}{l}R=-0.14 \\
P=0.36\end{array}$ & $\begin{array}{l}R=0.05 \\
P=0.72\end{array}$ & $\begin{array}{l}R=0.26 \\
P=0.10\end{array}$ \\
\hline Sputum macrophages, \% & $\begin{array}{l}R=0.11 \\
P=0.47\end{array}$ & $\begin{array}{l}R=0.20 \\
P=0.20\end{array}$ & $\begin{array}{l}R=-0.026 \\
P=0.87\end{array}$ & $\begin{array}{l}R=-0.02 \\
P=0.86\end{array}$ & $\begin{array}{l}R=-0.12 \\
P=0.45\end{array}$ \\
\hline Sputum neutrophils, \% & $\begin{array}{l}R=-0.02 \\
P=0.87\end{array}$ & $\begin{array}{l}R=-0.13 \\
P=0.42\end{array}$ & $\begin{array}{l}R=0.08 \\
P=0.58\end{array}$ & $\begin{array}{l}R=0.20 \\
P=0.21\end{array}$ & $\begin{array}{l}R=0.05 \\
P=0.74\end{array}$ \\
\hline Sputum lymphocytes, \% & $\begin{array}{l}R=-0.10 \\
P=0.50\end{array}$ & $\begin{array}{l}R=-0.1 I \\
P=0.47\end{array}$ & $\begin{array}{l}R=0.01 \\
P=0.93\end{array}$ & $\begin{array}{l}R=-0.01 \\
P=0.92\end{array}$ & $\begin{array}{l}R=-0.21 \\
P=0.17\end{array}$ \\
\hline Sputum eosinophils, \% & $\begin{array}{l}R=-0.08 \\
P=0.60\end{array}$ & $\begin{array}{l}R=-0.08 \\
P=0.60\end{array}$ & $\begin{array}{l}R=-0.03 \\
P=0.83\end{array}$ & $\begin{array}{l}R=-0.09 \\
P=0.55\end{array}$ & $\begin{array}{l}R=0.59 \\
P<0.0001\end{array}$ \\
\hline
\end{tabular}

Notes: BODE index, BMI, airway obstruction, dyspnea, exercise capacity.

Abbreviations: PBMC, peripheral blood mononuclear cells; BMI, body mass index, CAT, COPD Assessment Test; mMRC, modified Medical Research Council dyspnea scale; 6MWT, six-minute walk test.

hydrolase gene family, which encompasses chitinase-like proteins, also known as chi-lectins, which bind chitin with high affinity but lack enzymatic activity. ${ }^{1,4}$ However, no endogenous substrate for these enzymes has been identified in humans, multiple recent studies suggest that chitinases and structurally related chi-lectins (eg, chitinase 3-like 1 CHI3L1/YKL-40) play significant roles in inflammation, tissue injury, and repair responses contributing to the pathogenesis of various human diseases. ${ }^{1,5,60-62}$
CHIT1 is the best-characterized true chitinase from a clinical and biological perspective, ${ }^{60}$ and it has been shown to be the primary chitinase responsible for chitinolytic activity in the human lung. ${ }^{42}$ It is produced mainly by activated macrophages, neutrophils, and epithelial cells both in normal and diseased tissues. ${ }^{32,43,60,63}$ Both macrophages and neutrophils are known to play the pivotal roles in the innate immune responses, suggesting an active role of CHIT1 in maintaining the homeostasis in the innate 
immune system. ${ }^{64}$ Although the exact mechanism of its function is not fully defined, CHIT1 plays an important role in the defense against chitin-containing pathogens, including fungi, bacteria, and insects, along with a significant role in both acute and chronic inflammatory conditions. ${ }^{1,60,65} \mathrm{Up}$ to date published reports regarding CHIT1 levels in COPD are few. ${ }^{27,43}$

YKL-40 belongs to the mammalian chitinase-like protein family members, which bind chitin with high affinity, but lack chitinolytic activity. It is produced by various cell types, including macrophages, neutrophils, monocytes, airway epithelial cells, vascular smooth muscle cells, chondrocytes, synovial cells, and breast cells. ${ }^{66,67}$ The exact role of YKL-40 is not completely clear, but as an inflammatory molecule, it is thought to be involved in pathophysiological processes, including cell growth, migration, chemotaxis, and tissue remodeling. Dysregulated expression of YKL-40 has been reported in a number of human diseases characterized by acute or chronic inflammation and tissue remodeling. ${ }^{1}$ However, an exact biological role of YKL-40 remains to be elucidated. A recent systemic review and meta-analysis of available data suggest that YKL-40 may be involved in the pathogenesis of COPD, including bronchial inflammation and remodeling. ${ }^{68}$

The present study aimed to examine peripheral blood and sputum chitotriosidase and YKL-40 protein, activity and gene expression in patients with COPD. In contrast to previous observations reporting elevated protein $^{43}$ and activity levels ${ }^{27}$ of CHIT1 in peripheral blood of COPD patients, our results have not confirmed this finding in systemic compartment. Noted CHIT1 serum protein and activity levels were numerically higher in COPD and healthy smokers but did not differ significantly from healthy non-smokers. One of the possible reasons for noted discrepancies may be a small sample of advanced COPD patients with $\mathrm{FEV}_{1}<50 \%$ of predicted value in our study (only 9 of 40 COPD subjects studied). This possible explanation seems to be in line with the previous report of no difference in CHIT1 serum protein levels between COPD patients with $\mathrm{FEV}_{1}>50 \%$ of predicted value and subjects without COPD ${ }^{43}$ Another one could be that some humans are completely deficient in active CHIT1 which results from a 24-bp duplication in the CHIT1 gene leading to aberrant splicing and, consequently, the production of an enzymatically inactive protein. ${ }^{27,42,69}$ In our view, this is far less probable as such a CHIT1 genetic polymorphism is rare. In a recent study conducted in the COPD cohort, it was found in as low as $2.3 \%$ of subjects. ${ }^{27}$ Analysis of CHIT1 gene expression levels in our study showed increased CHIT1 mRNA expression in PBMC of COPD patients compared with healthy never-smokers. A significant relationship between CHIT1 mRNA expression in PBMC of COPD subjects and pack-years of cigarette smoking was noted. As far as we know, this finding has not been reported previously. However, a significant association between serum chitotriosidase activity and pack-years was observed in a recent study of COPD subjects. ${ }^{27}$ Activated macrophages are the primary source of CHIT1 in humans. ${ }^{32,43}$ Macrophages are monocytes that have migrated from the bloodstream into any tissue in the body; therefore, in our opinion upregulation of CHIT1 gene expression in PBMC is mainly due to monocytes component. The current study has not confirmed previous observations of serum CHIT1 and YKL-40 correlation with age $e^{27,70,71}$ and severity of airway obstruction in patients with COPD. ${ }^{27,43,68}$

We noted elevated levels of YKL-40 in serum of patients with COPD compared to healthy never-smokers. This finding is in accordance with the previous reports of elevated circulating YKL-40 in patients with COPD compared to healthy controls. ${ }^{68}$ YKL-40 serum level was also significantly elevated in healthy smokers compared to healthy never-smokers, which is in complete agreement with previous results reporting increased serum and lung YKL-40 levels in healthy smokers compared to neversmokers. ${ }^{72}$ The similar pattern of elevated YKL-40 levels in both patients with COPD and healthy smokers was observed in PBMC gene expression data. It seems that cigarette smoke activates macrophages, neutrophils, and alveolar epithelial cells for production and further accumulation of YKL-40 during smoking exposure in subjects without COPD and this phenomenon is likely to be continued in COPD subjects regardless of active smoking. This persuasion is strengthened by a significant association of serum YKL-40 and sputum neutrophils cell count as well as association of YKL-40 PBMC mRNA expression and disease duration in COPD subjects noted in our study. Those findings have not been previously reported in studies of YKL-40 in COPD. ${ }^{68}$ Therefore, we and others demonstrated a significant effect of active cigarette smoking on YKL-40 expression. The exact mechanism by which smoking activates the release of chitinases is unclear. One of the possible hypotheses is that chitin particles are inhaled with tobacco smoke due to fungal contamination of the tobacco leaf. ${ }^{73}$ However, the precise mechanism by which smoking causes activation of chitinases remains to be elucidated. 
To date, no data exist regarding CHIT1 levels in the induced sputum of COPD subjects, although, this technique has been successfully applied in COPD studies assessing sputum levels of YKL- $40 .{ }^{47,48}$ We have demonstrated elevated sputum levels of CHIT1 in COPD patients compared to healthy never-smokers. Our results of increased sputum protein and activity CHIT1 levels in patients with COPD are in accordance with the previous reports of increased CHIT1 levels in lung samples including $\mathrm{BAL}^{32,42}$ and lung tissue. ${ }^{43}$ Interestingly, we have found elevated sputum CHIT1 activity in a subgroup of COPD patients without airway eosinophilic inflammation (sputum eosinophilia $\leq 3 \%$ ) compared to COPD patients with airway eosinophilic inflammation (sputum eosinophilia $>3 \%$ ). Eosinophils may play a significant role in airway inflammation in some patients with $\mathrm{COPD}^{74}$ and studies indicate that up to a third of patients with COPD have sputum eosinophilia. ${ }^{75}$ A growing body of evidence indicates that elevated eosinophil counts have been associated with reduced lung function and increased risk of exacerbations in patients with COPD. ${ }^{76}$ It may be assumed that human CHIT1 has possible protective role against rapid disease progression in COPD subjects without airway eosinophilia, although the possible underlying mechanism remains to be elucidated. It is of note that our study may not have been well powered to perform sputum eosinophil dependent analysis in COPD cohort. As this was preliminary and not confirmatory study, therefore the sample size estimation and power analysis were not calculated. Thus, further studies are warranted to confirm our study results and to evaluate biological significance of our findings. CHIT1 gene expression analysis in sputum showed its elevated levels in healthy smokers compared to healthy never-smokers. This may support, discussed above, significant effect of active smoking on chitinases expression, however the exact mechanism remains unclear. Our finding of negative correlation between CHIT1 sputum activity and age is in contradiction with previous results reported in the literature demonstrating that serum levels of both CHIT1 and YKL-40 increase with age. ${ }^{27,70,71}$ Similarly, we have not found an association between sputum chitotriosidase and YKL-40 levels and reduced lung function, which has been previously reported in COPD studies assessing chitinases expression in peripheral blood. ${ }^{27,43,68}$ Even though these results differ from some previously published it could nevertheless be argued that we studied different compartment and more data is needed to clarify inconsistency of those findings.
We noted elevated sputum YKL-40 levels in COPD subjects compared to healthy never-smokers. This finding substantiates previous reports of elevated sputum YKL-40 in patients with COPD compared to healthy controls. ${ }^{47,48}$ However, our study has not confirmed previous finding of a significant correlation of sputum YKL-40 levels with sputum neutrophils and macrophages counts in COPD. ${ }^{47}$ Surprisingly, we found significant association between sputum YKL-40 mRNA expression and sputum eosinophils cell counts. Eosinophils are not considered to be an important cellular source of YKL-40. ${ }^{66,67}$ Interestingly, we noted a significant association of sputum YKL-40 levels and time since COPD diagnosis. As far as we are aware this is the first study reporting correlation between sputum YKL-40 and disease duration in COPD. Together with present study peripheral blood data confirming association between YKL-40 PBMC mRNA expression and disease duration, these findings widen current knowledge on chitinases expression in COPD. Their levels may not only correlate with age and severity of airway obstruction as previously reported, ${ }^{27,43,68}$ but also with disease duration as shown in our study.

Additional analyses of chitotriosidase and YKL-40 peripheral blood and sputum levels in subgroups of COPD patients based on the disease exacerbation history surprisingly showed elevated YKL-40 sputum mRNA expression levels in subgroup of patients without exacerbation history and low risk for future exacerbations compared with subgroup with exacerbation history and high risk for future exacerbations. None of the previous studies performed in COPD cohorts reported analyses of its expression in relation to patients' exacerbation history. However, a recent meta-analysis and systematic review of YKL-40 studies in COPD reported elevated levels of circulating YKL-40 during acute exacerbation of COPD compared with stable disease periods. ${ }^{68}$ Interestingly, we have found elevated sputum CHIT1 concentration and activity levels in subgroup of COPD patients with high risk for future exacerbations. To the best of authors knowledge, this finding has not been reported previously. In the light of our preliminary findings of elevated activity levels of CHIT1 in COPD patients without airway eosinophilic inflammation, it would be particularly interesting to study CHIT1 expression levels in COPD patients during acute disease exacerbation, as heterogeneity of biologic response of COPD exacerbations can be defined and includes eosinophilic and non-eosinophilic phenotypes. ${ }^{77}$ Certainly, further studies of CHIT1 and YKL-40 in COPD are 
warranted to determine their biologic significance in the disease pathophysiology.

The present study has several limitations, the most important being a relatively small sample size, and difference in age between COPD subjects and healthy smokers and never-smokers studied. As according to published data, chitinases levels increase with age in both healthy and COPD subjects ${ }^{27,70,71}$ the slight difference of age between studied cohorts could have influenced the results obtained. However, in our study neither chitotriosidase, nor YKL-40 correlated positively with age. It is plausible that a small sample size studied could result in some discrepancies between our results and previous research. Furthermore, smoking exposure quantified in pack-years was significantly lower in healthy smokers compared with the COPD patients participating in the present study. Taking into account a significant effect of cigarette smoking on chitinases expression this makes it a potential limitation of the study. Different comorbidities, which are common for COPD subjects, are also important factors that could possibly influence obtained results. Despite the fact, that present study has several limitations, in our opinion its unique construction and complex assessment of chitotriosidase and YKL-40 expression together with the novelty of findings fill a gap in the literature on the role of chitinases and chitin-like proteins in the pathophysiology of COPD.

\section{Conclusions}

The findings of this study indicate that chitotriosidase and YKL-40 are overexpressed in peripheral blood and airways in both healthy smokers and COPD subjects which may indicate smoking-related activation of macrophages, neutrophils, and epithelial cells.

\section{Acknowledgments}

This work was funded by Medical University of Lodz. The costs of this study were defrayed from regular finances of the Department of Pneumology and Allergy 503/1-151-03/ 503-11-002-18. The abstract version of this paper was presented at the 28th ERS International Congress in Paris as a poster presentation with interim findings and the poster's abstract has been published. ${ }^{78}$

\section{Author contributions}

Study conception - SM and PG; design - SM, DT, EBL, AA, WJP, PG; acquisition of data - SM, DT, KS, JK, ZK, HJ. All authors contributed to data analysis, drafting or revising the article, gave final approval of the version to be published, and agree to be accountable for all aspects of the work.

\section{Disclosure}

The authors report no conflicts of interest in this work.

\section{References}

1. Lee CG, Da Silva CA, Dela Cruz CS, et al. Role of chitin and chitinase/chitinase-like proteins in inflammation, tissue remodeling, and injury. Аnпu Rev Physiol. 2011;73:479-501. doi:10.1146/ annurev-physiol-012110-142250

2. Fusetti F, von Moeller H, Houston D, et al. Structure of human chitotriosidase. Implications for specific inhibitor design and function of mammalian chitinase-like lectins. J Biol Chem. 2002;277 (28):25537-25544. doi:10.1074/jbc.M201636200

3. Boot RG, Bussink AP, Verhoek M, de Boer PAJ, Moorman AFM, Aerts JMFG. Marked differences in tissue-specific expression of chitinases in mouse and man. J Histochem Cytochem Off J Histochem Soc. 2005;53 (10):1283-1292. doi:10.1369/jhc.4A6547.2005

4. Bussink AP, Speijer D, Aerts JMFG, Boot RG. Evolution of mammalian chitinase(-like) members of family 18 glycosyl hydrolases. Genetics. 2007;177(2):959-970. doi:10.1534/genetics.107.075846

5. Adrangi S, Faramarzi MA. From bacteria to human: A journey into the world of chitinases. Biotechnol Adv. 2013;31(8):1786-1795. doi:10.1016/j.biotechadv.2013.09.012

6. Dela Cruz CS, Liu W, He CH, et al. Chitinase 3-like-1 promotes Streptococcus pneumoniae killing and augments host tolerance to lung antibacterial responses. Cell Host Microbe. 2012;12(1):34-46. doi:10.1016/j.chom.2012.05.017

7. Marion CR, Wang J, Sharma L, et al. Chitinase 3-like 1 (Chil1) regulates survival and macrophage-mediated interleukin- $1 \beta$ and tumor necrosis factor alpha during pseudomonas aeruginosa pneumonia. Infect Immun. 2016;84(7):2094-2104. doi:10.1128/IAI.00055-16

8. Wang H-L, Hsiao P-C, Tsai H-T, Yeh C-B, Yang S-F. Usefulness of plasma YKL-40 in management of community-acquired pneumonia severity in patients. Int $J$ Mol Sci. 2013;14(11):22817-22825. doi:10.3390/ijms141122817

9. Spoorenberg SMC, Vestjens SMT, Rijkers GT, et al. YKL-40, CCL18 and SP-D predict mortality in patients hospitalized with communityacquired pneumonia. Respirol Carlton Vic. 2017;22(3):542-550. doi:10.1111/resp.12924

10. Østergaard C, Johansen JS, Benfield T, Price PA, Lundgren JD. YKL40 is elevated in cerebrospinal fluid from patients with purulent meningitis. Clin Diagn Lab Immunol. 2002;9(3):598-604. doi:10.1128/cdli.9.3.598-604.2002

11. Gong Z, Xing S, Zheng F, Xing Q. Increased expression of chitinase 3-like 1 in aorta of patients with atherosclerosis and suppression of atherosclerosis in apolipoprotein E-knockout mice by chitinase 3-like 1 gene silencing. Mediators Inflamm. 2014;2014:905463. doi:10. $1155 / 2014 / 905463$

12. Wu S, Hsu L-A, Cheng S-T, et al. Circulating YKL-40 level, but not CHI3L1 gene variants, is associated with atherosclerosis-related quantitative traits and the risk of peripheral artery disease. Int $J$ Mol Sci. 2014;15(12):22421-22437. doi:10.3390/ijms151222421

13. Di Rosa M, Malaguarnera L. Chitinase 3 like-1: an emerging molecule involved in diabetes and diabetic complications. Pathobiol $J$ Immunopathol Mol Cell Biol. 2016;83(5):228-242. doi:10.1159/ 000444855

14. Buisson A, Vazeille E, Minet-Quinard R, et al. Faecal chitinase 3-like 1 is a reliable marker as accurate as faecal calprotectin in detecting endoscopic activity in adult patients with inflammatory bowel diseases. Aliment Pharmacol Ther. 2016;43(10):1069-1079. doi:10.1111/apt.13585 
15. Nielsen KR, Steffensen R, Boegsted M, et al. Promoter polymorphisms in the chitinase 3-like 1 gene influence the serum concentration of YKL-40 in Danish patients with rheumatoid arthritis and in healthy subjects. Arthritis Res Ther. 2011;13(3):R109. doi:10.1186/ar3391

16. Sekine T, Masuko-Hongo K, Matsui T, et al. Recognition of YKL-39, a human cartilage related protein, as a target antigen in patients with rheumatoid arthritis. Ann Rheum Dis. 2001;60(1):49-54. doi:10.1136/ ard.60.1.49

17. Wcisło-Dziadecka D, Kotulska A, Brzezińska-Wcisło L, Kucharz EJ, Lis-Swiety A, Kamińska-Wiciorek G. Serum human cartilage glycoprotein-39 levels in patients with systemic lupus erythematosus. Pol Arch Med Wewn. 2009;119(12):777-784.

18. Kjaergaard AD, Bojesen SE, Nordestgaard BG, Johansen JS. YKL40 and alcoholic liver and pancreas damage and disease in 86,258 individuals from the general population: cohort and mendelian randomization studies. Clin Chem. 2014;60(11):1429-1440. doi:10.1373/clinchem.2014.229096

19. Kumagai E, Mano Y, Yoshio S, et al. Serum YKL-40 as a marker of liver fibrosis in patients with non-alcoholic fatty liver disease. Sci Rep. 2016;6:35282. doi:10.1038/srep35282

20. Rusak A, Jablonska K, Piotrowska A, et al. The role of CHI3L1 expression in angiogenesis in invasive ductal breast carcinoma. Anticancer Res. 2018;38(6):3357-3366. doi:10.21873/ anticanres. 12602

21. Väänänen T, Kallio J, Vuolteenaho K, et al. High YKL-40 is associated with poor survival in patients with renal cell carcinoma: a novel independent prognostic marker. Scand J Urol. 2017;51(5):367372. doi:10.1080/21681805.2017.1327885

22. Salomon J, Piotrowska A, Matusiak Ł, Dzięgiel P, Szepietowski JC. Chitinase-3-like protein 1 (YKL-40) expression in squamous cell skin cancer. Anticancer Res. 2018;38(8):4753-4758. doi:10.21873/ anticanres. 12783

23. Wan G, Xiang L, Sun X, et al. Elevated YKL-40 expression is associated with a poor prognosis in breast cancer patients. Oncotarget. 2017;8(3):5382-5391. doi:10.18632/oncotarget.14280

24. Gomez JL, Crisafi GM, Holm CT, et al. Genetic variation in chitinase 3-like 1 (CHI3L1) contributes to asthma severity and airway expression of YKL-40. J Allergy Clin Immunol. 2015;136(1):51-58.e10. doi:10.1016/j.jaci.2014.11.027

25. Komi DEA, Kazemi T, Bussink AP. New insights into the relationship between chitinase-3-like-1 and asthma. Curr Allergy Asthma Rep. 2016;16(8):57. doi:10.1007/s11882-016-0637-2

26. Specjalski K, Chełmińska M, Jassem E. YKL-40 protein correlates with the phenotype of asthma. Lung. 2015;193(2):189-194. doi:10.1007/s00408-015-9693-y

27. James AJ, Reinius LE, Verhoek M, et al. Increased YKL-40 and chitotriosidase in asthma and chronic obstructive pulmonary disease. Am J Respir Crit Care Med. 2016;193(2):131-142. doi:10.1164/ rccm.201504-07600C

28. Lai T, Wu D, Chen M, et al. YKL-40 expression in chronic obstructive pulmonary disease: relation to acute exacerbations and airway remodeling. Respir Res. 2016;17:31. doi:10.1186/s12931-016-0338-3

29. Gumus A, Kayhan S, Cinarka H, et al. High serum YKL-40 level in patients with COPD is related to hypoxemia and disease severity. Tohoku J Exp Med. 2013;229(2):163-170.

30. Létuvé S, Kozhich A, Arouche N, et al. YKL-40 is elevated in patients with chronic obstructive pulmonary disease and activates alveolar macrophages. J Immunol Baltim Md 1950. 2008;181(7):5167-5173.

31. Holmgaard DB, Mygind LH, Titlestad IL, et al. Plasma YKL-40 and all-cause mortality in patients with chronic obstructive pulmonary disease. BMC Pulm Med. 2013;13:77. doi:10.1186/14712466-13-77

32. Létuvé S, Kozhich A, Humbles A, et al. Lung chitinolytic activity and chitotriosidase are elevated in chronic obstructive pulmonary disease and contribute to lung inflammation. Am J Pathol. 2010;176 (2):638-649. doi:10.2353/ajpath.2010.090455
33. Long $\mathrm{X}, \mathrm{He} \mathrm{X}$, Ohshimo S, et al. Serum YKL-40 as predictor of outcome in hypersensitivity pneumonitis. Eur Respir J. 2017;49:2. doi:10.1183/13993003.01924-2015

34. Johansen JS, Milman N, Hansen M, Garbarsch C, Price PA, Graudal $\mathrm{N}$. Increased serum YKL-40 in patients with pulmonary sarcoidosisa potential marker of disease activity? Respir Med. 2005;99(4):396402. doi:10.1016/j.rmed.2004.09.016

35. Kruit A, Grutters JC, Ruven HJT, van Moorsel CCM, van Den Bosch JMM. A CHI3L1 gene polymorphism is associated with serum levels of YKL-40, a novel sarcoidosis marker. Respir Med. 2007;101 (7):1563-1571. doi:10.1016/j.rmed.2006.12.006

36. Bargagli E, Maggiorelli C, Rottoli P. Human chitotriosidase: a potential new marker of sarcoidosis severity. Respir Int Rev Thorac Dis. 2008;76(2):234-238. doi:10.1159/000134009

37. Furuhashi K, Suda T, Nakamura Y, et al. Increased expression of YKL-40, a chitinase-like protein, in serum and lung of patients with idiopathic pulmonary fibrosis. Respir Med. 2010;104(8):1204-1210. doi:10.1016/j.rmed.2010.02.026

38. Korthagen NM, van Moorsel CHM, Barlo NP, et al. Serum and BALF YKL-40 levels are predictors of survival in idiopathic pulmonary fibrosis. Respir Med. 2011;105(1):106-113. doi:10.1016/j. rmed.2010.09.012

39. Korthagen NM, van Moorsel CHM, Zanen P, Ruven HJ, Grutters JC. Evaluation of circulating YKL-40 levels in idiopathic interstitial pneumonias. Lung. 2014;192(6):975-980. doi:10.1007/s00408-014-9647-9

40. Barnes PJ. Chronic obstructive pulmonary disease. $N$ Engl J Med. 2000;343(4):269-280. doi:10.1056/NEJM200007273430407

41. Hogg JC. Pathophysiology of airflow limitation in chronic obstructive pulmonary disease. Lancet Lond Engl. 2004;364(9435):709-721. doi:10.1016/S0140-6736(04)16900-6

42. Seibold MA, Donnelly S, Solon M, et al. Chitotriosidase is the primary active chitinase in the human lung and is modulated by genotype and disease. J Allergy Clin Immunol. 2008;122(5):944950.e3. doi:10.1016/j.jaci.2008.08.023

43. Agapov E, Battaile JT, Tidwell R, et al. Macrophage chitinase 1 stratifies chronic obstructive lung disease. Am J Respir Cell Mol Biol. 2009;41(4):379-384. doi:10.1165/2009-0122R

44. Sakazaki Y, Hoshino T, Takei S, et al. Overexpression of chitinase 3-like 1/ YKL-40 in lung-specific IL-18-transgenic mice, smokers and COPD. PLoS One. 2011;6(9):e24177. doi:10.1371/journal.pone.0024177

45. Han S-S, Lee WH, Hong Y, et al. Comparison of serum biomarkers between patients with asthma and with chronic obstructive pulmonary disease. J Asthma Off J Assoc Care Asthma. 2016;53(6):583-588. doi:10.3109/02770903.2015.1056347

46. Shirai T, Hirai K, Gon Y, et al. Combined Assessment of Serum periostin and YKL-40 may identify asthma-COPD overlap. J Allergy Clin Immunol Pract. 2019;7(1):134-145.e1. doi:10.1016/j.jaip.2018.06.015

47. Otsuka K, Matsumoto H, Niimi A, et al. Sputum YKL-40 levels and pathophysiology of asthma and chronic obstructive pulmonary disease. Respir Int Rev Thorac Dis. 2012;83(6):507-519. doi:10.1159/ 000330840

48. Gao J, Iwamoto $\mathrm{H}$, Koskela $\mathrm{J}$, et al. Characterization of sputum biomarkers for asthma-COPD overlap syndrome. Int $J$ Chron Obstruct Pulmon Dis. 2016;11:2457-2465. doi:10.2147/COPD. S113484

49. Tworek D, Majewski S, Szewczyk K, et al. The association between airway eosinophilic inflammation and IL-33 in stable non-atopic COPD. Respir Res. 2018;19(1):108. doi:10.1186/s12931-018-0807-y

50. Majewski S, Pietrzak A, Tworek D, et al. Skin condition and its relationship to systemic inflammation in chronic obstructive pulmonary disease. Int J Chron Obstruct Pulmon Dis. 2017;12:2407-2415. doi:10.2147/COPD.S141805

51. GOLD 2017. Global strategy for the diagnosis, management and prevention of COPD. Glob Initiat Chronic Obstr Lung Dis. 2016. Available from: https://goldcopd.org/gold-2017-global-strategy-diag nosis-management-prevention-copd/. Accessed August 12, 2018. 
52. Miller MR, Hankinson J, Brusasco V, et al. Standardisation of spirometry. Eur Respir J. 2005;26(2):319-338. doi:10.1183/09031936.05.00034805

53. Majewski S, Cichocki P, Stępnicka-Bindemann M, Górski P. Asthma control, quality of life and successful sputum induction. Arch Med Sci. 2011;7(5):840-843. doi:10.5114/aoms.2011.25559

54. Pavord ID, Pizzichini MM, Pizzichini E, Hargreave FE. The use of induced sputum to investigate airway inflammation. Thorax. 1997;52 (6):498-501.

55. Haldar P, Pavord ID. Noneosinophilic asthma: a distinct clinical and pathologic phenotype. J Allergy Clin Immunol. 2007;119(5):10431052;quiz 1053-1054. doi:10.1016/j.jaci.2007.02.042

56. Mahler DA, Wells CK. Evaluation of clinical methods for rating dyspnea. Chest. 1988;93(3):580-586.

57. Jones PW, Harding G, Berry P, Wiklund I, Chen W-H, Kline Leidy N. Development and first validation of the COPD assessment test. Eur Respir J. 2009;34(3):648-654. doi:10.1183/09031936.00102509

58. Przybyłowski T, Tomalak W, Siergiejko Z, et al. Polish respiratory society guidelines for the methodology and interpretation of the 6 min walk test (6MWT). Pneumonol Alergol Pol. 2015;83(4):283297. doi:10.5603/PiAP.2015.0048

59. Cote CG, Celli BR. BODE index: a new tool to stage and monitor progression of chronic obstructive pulmonary disease. Pneumonol Alergol Pol. 2009;77(3):305-313.

60. Kanneganti M, Kamba A, Mizoguchi E. Role of chitotriosidase (chitinase 1) under normal and disease conditions. J Epithel Biol Pharmacol. 2012;5:1-9.

61. Kawada M, Hachiya Y, Arihiro A, Mizoguchi E. Role of mammalian chitinases in inflammatory conditions. Keio J Med. 2007;56(1):21-27.

62. Johansen JS. Studies on serum YKL-40 as a biomarker in diseases with inflammation, tissue remodelling, fibroses and cancer. Dan Med Bull. 2006;53(2):172-209.

63. van Eijk M, van Roomen CPAA, Renkema GH, et al. Characterization of human phagocyte-derived chitotriosidase, a component of innate immunity. Int Immunol. 2005;17(11):1505-1512. doi:10.1093/intimm/dxh328

64. Elias JA, Homer RJ, Hamid Q, Lee CG. Chitinases and chitinase-like proteins in $\mathrm{T}(\mathrm{H}) 2$ inflammation and asthma. J Allergy Clin Immunol. 2005;116(3):497-500. doi:10.1016/j.jaci.2005.06.028

65. Malaguarnera L. Chitotriosidase: the yin and yang. Cell Mol Life Sci. 2006;63(24):3018-3029. doi:10.1007/s00018-006-6269-2

66. Recklies AD, White $\mathrm{C}$, Ling $\mathrm{H}$. The chitinase 3-like protein human cartilage glycoprotein 39 (HC-gp39) stimulates proliferation of human connective-tissue cells and activates both extracellular signal-regulated kinase- and protein kinase B-mediated signalling pathways. Biochem J. 2002;365(Pt 1):119-126. doi:10.1042/BJ20020075
67. Shao R, Hamel K, Petersen L, et al. YKL-40, a secreted glycoprotein, promotes tumor angiogenesis. Oncogene. 2009;28(50):4456-4468. doi:10.1038/onc.2009.292

68. Tong X, Wang D, Liu S, et al. The YKL-40 protein is a potential biomarker for COPD: a meta-analysis and systematic review. Int J Chron Obstruct Pulmon Dis. 2018;13:409-418. doi:10.2147/COPD.S152655

69. Boot RG, Renkema GH, Verhoek M, et al. The human chitotriosidase gene. Nature of inherited enzyme deficiency. J Biol Chem. 1998;273 (40):25680-25685.

70. Kurt I, Abasli D, Cihan M, et al. Chitotriosidase levels in healthy elderly subjects. Ann N Y Acad Sci. 2007;1100:185-188. doi:10.1196/ annals. 1395.017

71. Bojesen SE, Johansen JS, Nordestgaard BG. Plasma YKL-40 levels in healthy subjects from the general population. Clin Chim Acta Int J Clin Chem. 2011;412(9-10):709-712. doi:10.1016/j.cca.2011.01.022

72. Matsuura H, Hartl D, Kang M-J, et al. Role of breast regression protein-39 in the pathogenesis of cigarette smoke-induced inflammation and emphysema. Am J Respir Cell Mol Biol. 2011;44(6):777786. doi:10.1165/rcmb.2010-0081OC

73. Verweij PE, Kerremans JJ, Voss A, Meis JF. Fungal contamination of tobacco and marijuana. JAMA. 2000;284(22):2875.

74. Saha S, Brightling CE. Eosinophilic airway inflammation in COPD. Int J Chron Obstruct Pulmon Dis. 2006;1(1):39-47.

75. Eltboli O, Bafadhel M, Hollins F, et al. COPD exacerbation severity and frequency is associated with impaired macrophage efferocytosis of eosinophils. BMC Pulm Med. 2014;14:112. doi:10.1186/14712466-14-112

76. Tashkin DP, Wechsler ME. Role of eosinophils in airway inflammation of chronic obstructive pulmonary disease. Int J Chron Obstruct Pulmon Dis. 2018;13:335-349. doi:10.2147/COPD.S152291

77. Bafadhel M, McKenna S, Terry S, et al. Acute exacerbations of chronic obstructive pulmonary disease: identification of biologic clusters and their biomarkers. Am J Respir Crit Care Med. 2011;184(6):662-671. doi:10.1164/rccm.201104-0597OC

78. Majewski S, Tworek D, Szewczyk K, et al. Overexpression of chitotriosidase and YKL-40 in serum and sputum in healthy smokers and patients with chronic obstructive pulmonary disease. Eur Respir J. 2018;52 (suppl62):PA2022. doi:10.1183/13993003.congress-2018.PA2022

\section{Publish your work in this journal}

The International Journal of COPD is an international, peer-reviewed journal of therapeutics and pharmacology focusing on concise rapid reporting of clinical studies and reviews in COPD. Special focus is given to the pathophysiological processes underlying the disease, intervention programs, patient focused education, and self managemen protocols. This journal is indexed on PubMed Central, MedLine and CAS. The manuscript management system is completely online and includes a very quick and fair peer-review system, which is all easy to use. Visit http://www.dovepress.com/testimonials.php to read real quotes from published authors. 